\title{
Untangling the dorsal diencephalic conduction system: a review of structure and function of the stria medullaris, habenula and fasciculus retroflexus
}

\author{
Elena Roman \\ Trinity College Dublin, Ireland \\ Joshua Weininger \\ Trinity College Dublin, Ireland \\ Basil Lim \\ Technological University Dublin, basil.lim@tudublin.ie
}

See next page for additional authors

Follow this and additional works at: https://arrow.tudublin.ie/aaschmedoth

Part of the Medical Sciences Commons

\section{Recommended Citation}

Roman E, Weininger J, Lim B, Roman M, Barry D, Tierney P, O'Hanlon E, Levins K, O'Keane V, Roddy D. Untangling the dorsal diencephalic conduction system: a review of structure and function of the stria medullaris, habenula and fasciculus retroflexus. Brain Struct Funct. 2020 Jun;225(5):1437-1458. doi: 10.1007/s00429-020-02069-8. Epub 2020 May 4. PMID: 32367265.

This Article is brought to you for free and open access by the School of Media at ARROW@TU Dublin. It has been accepted for inclusion in Other by an authorized administrator of ARROW@TU Dublin. For more information, please contact arrow.admin@tudublin.ie, aisling.coyne@tudublin.ie,gerard.connolly@tudublin.ie.

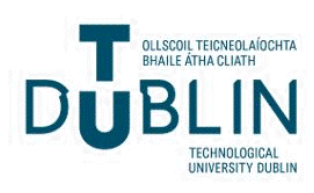




\section{Authors}

Elena Roman, Joshua Weininger, Basil Lim, Marin Roman, Denis Barry, Paul Tierney, Erik O'Hanlon, Kirk Levins, Veronica O'Keane, and Darren Roddy 


\title{
Untangling the dorsal diencephalic conduction system: a review of structure and function of the stria medullaris, habenula and fasciculus retroflexus
}

\author{
Elena Roman ${ }^{1,2} \cdot$ Joshua Weininger $^{1} \cdot$ Basil Lim $^{1,3} \cdot$ Marin Roman $^{1} \cdot$ Denis Barry $^{4} \cdot$ Paul Tierney $^{4} \cdot$ Erik O'Hanlon $^{1,2}$. \\ Kirk Levins ${ }^{5} \cdot$ Veronica O'Keane ${ }^{1} \cdot$ Darren Roddy $^{1}{ }^{10}$
}

Received: 25 August 2019 / Accepted: 11 April 2020 / Published online: 4 May 2020

(c) Springer-Verlag GmbH Germany, part of Springer Nature 2020

\begin{abstract}
The often-overlooked dorsal diencephalic conduction system (DDCS) is a highly conserved pathway linking the basal forebrain and the monoaminergic brainstem. It consists of three key structures; the stria medullaris, the habenula and the fasciculus retroflexus. The first component of the DDCS, the stria medullaris, is a discrete bilateral tract composed of fibers from the basal forebrain that terminate in the triangular eminence of the stalk of the pineal gland, known as the habenula. The habenula acts as a relay hub where incoming signals from the stria medullaris are processed and subsequently relayed to the midbrain and hindbrain monoaminergic nuclei through the fasciculus retroflexus. As a result of its wide-ranging connections, the DDCS has recently been implicated in a wide range of behaviors related to reward processing, aversion and motivation. As such, an understanding of the structure and connections of the DDCS may help illuminate the pathophysiology of neuropsychiatric disorders such as depression, addiction and pain. This is the first review of all three components of the DDCS, the stria medullaris, the habenula and the fasciculus retroflexus, with particular focus on their anatomy, function and development.
\end{abstract}

Keywords Dorsal diencephalic conduction system $\cdot$ Stria medullaris $\cdot$ Habenula $\cdot$ Fasciculus retroflexus

\section{Introduction}

The dorsal diencephalic conduction system (DDCS) is a highly conserved integrative and modulatory pathway present in all vertebrates (Sutherland 1982). This bilateral assembly consists of two white matter tracts with an

Darren Roddy

dwroddy@tcd.ie

1 Department of Psychiatry, Trinity College Institute of Neuroscience, Trinity College Dublin, Dublin 2, Ireland

2 Department of Psychiatry, Education and Research Centre, Royal College of Surgeons in Ireland, Beaumont Hospital, Dublin 9, Ireland

3 Department of Game Design, Technological University Dublin, Dublin 2, Ireland

4 Anatomy Department, Trinity Biomedical Sciences Institute, Trinity College Dublin, Dublin 2, Ireland

5 Department of Anaesthetics, Intensive Care and Pain Medicine, St. Vincent's University Hospital, Dublin 4, Ireland intervening nucleus and is a key conduit connecting the cognitive-emotional basal forebrain to the modulatory monoamine areas of the brainstem (Sutherland 1982; Gardon et al. 2014). It is often overlooked in favor of its more ventral and larger companion, the medial forebrain bundle, which also connects the fore- and hindbrain regions. The similarity in connections (forebrain limbic-striatal to monoaminergic brainstem) and the fact that they converge upon each other anteriorly and posteriorly despite straddling either the dorsal (epithalamic route) or ventral (hypothalamic route) thalamus (Fig. 1) led Nauta to suggest that they may have similar functions with respect to reward behaviors (Nauta 1958). The DDCS first revealed a role in reward in 1970 (Boyd and Celso 1970) and subsequently also showed functionality in the 'top-down' modulation of motivation, mood and pain. Highly conserved amongst vertebrates, (Beretta et al. 2012; Concha and Wilson 2001) this system, unlike the singular component of the medial forebrain that forms direct connections (Coenen et al. 2018), is composed of three structures: the white matter stria medullaris, the intervening habenular nucleus and the white matter fasciculus 


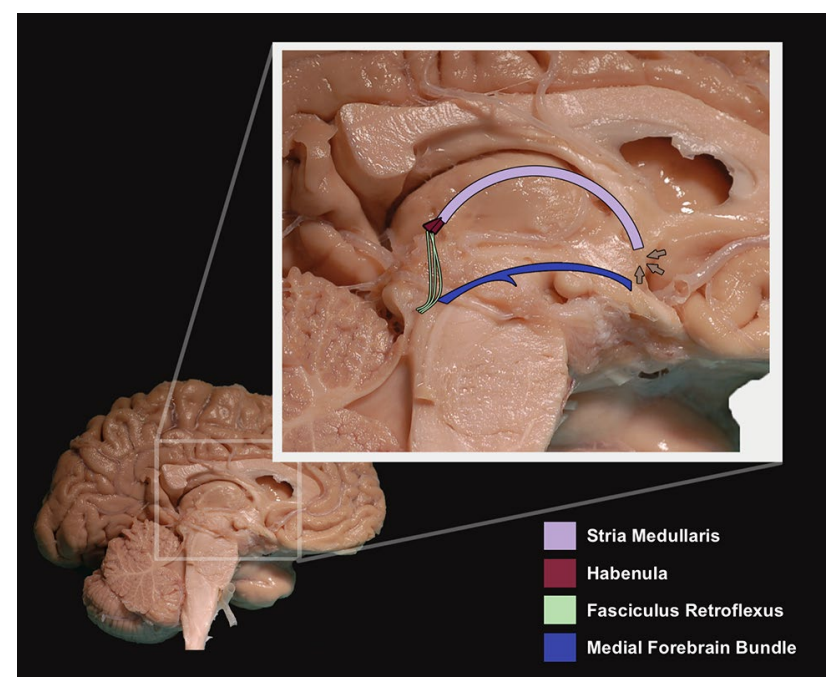

Fig. 1 The dorsal diencephalic conduction system, with the stria medullaris, habenula and fasciculus retroflexus highlighted. The SM can be seen arching over the thalamus and terminating in the $\mathrm{Hb}$. The larger more wedged-shaped LHb is labeled and can be distinguished from the smaller MHb. The FR can also be identified with fibers arising from the MHb running through the core of the FR and fibers arising from the LHb traveling in the mantle of the FR. Brain photography courtesy of Professor Paul Tierney, Head of Discipline, Department of Anatomy, Trinity College Dublin. SM Stria Medullaris, $H b$ habenula, $F R$ Fasciculus Retroflexus, $L H b$ Lateral Habenula, $M H b$ Medial Habenula

retroflexus. Gathering inputs from diverse frontal areas including the septal nuclei (pleasure and motivation), hypothalamus (arousal and pain), fronto-cortical regions (decision-making), and basal ganglia (motor and behavioral control), the stria medullaris funnels information from these regions into the habenula, situated at the dorso-caudal end of the thalamus (Parent et al. 1981; Geisler and Trimble 2008). Information flow in the SM is almost entirely unidirectional (forebrain to habenula), apart from some reciprocal fibers arising from the lateral preoptic and lateral hypothalamic areas (Yamadori 1969; Champney 2015; Patestas and Gartner 2016). After integrating these inputs and relaying in the habenula, output fibers project down through the fasciculus retroflexus to synapse among brainstem monoamine areas including the midbrain ventral tegmental area and hindbrain raphe nuclei. Through this system, distinct frontolimbic areas can modulate monoaminergic release in the brainstem and consequently influence whole brain monoaminergic tone.

In recent years, the DDCS has received increasing attention (Gardon et al. 2014; Fakhoury et al. 2016b; Roddy et al. 2018; Fore and Yaksi 2019; Ichijo and Toyama 2015), with research suggesting a particular role in neuropsychiatric disorders due to its function in monoamine regulation (Fakhoury 2017). This is the first review to collate the literature on the known anatomy, function and development of the human DDCS as a whole, as opposed to reviews which have focused exclusively on the habenula alone (Hikosaka et al. 2008; Hikosaka 2010; Fakhoury 2017; Bianco and Wilson 2009). Although initially aimed as a review of the human DDCS, due to the relative dearth of human studies, the review will be complemented by other vertebrate studies throughout.

\section{Methods}

A comprehensive literature search to investigate the range and destination (medial/lateral) of habenular inputs was undertaken for the purpose of this review. Online sources including PubMed/MEDLINE, Google Scholar, EMBASE, OVID, and PsycINFO were systematically searched by the primary and senior authors (ER and DWR) using the terms "HABENULA"|"DORSAL DEINCEPHALIC CONDUCTION SYSTEM"|"FASCICULUS RETROFLEXUS"/"HABENULOPEDUNCULAR TRACT"/"HABENULOINTERPEDUNCULAR TRACT" + "INPUT"/“EFFERENT"/"TRACING”/"C ONNECTIONS"/"MIDBRAIN"/HINDBRAIN". No time limit was imposed on search results. Once areas were identified, the search was rerun for each area separately, e.g., "HABENULA" + "HYPOTHALAMUS", "HABENULA" + "AMYGDALA". All vertebrate species were included in the search. For each article, references were checked and accessed if considered potentially relevant. A physical search of older literature and books archived in the Department of Anatomy, Trinity College Dublin was also undertaken. All studies were collated, and the data extracted and crosschecked by two researchers (ER and JW).

To determine the mean volume of the habenula, we analyzed data from 14 studies examining normal habenulae (i.e., studies examining habenulae volumes in normal individuals, or control data from clinical studies) in a total of 356 subjects (excluding data from repeated studies). Data were extracted from the results of these studies, and the authors contacted if the raw data was unavailable from published sources. Many study data sets were unavailable and, therefore, mean habenular volumes could not be calculated. As such using the SPSS 24 "compute" command, the MEAN function was used to generate an available analysis (AIA) scale for the missing data (Parent 2013).

\section{Stria medullaris}

(Latin; inner strip/furrow) The stria medullaris (SM), also known as stria medullaris thalami or habenular stria, is a discrete bilateral white matter tract forming the first part of the dorsal diencephalic conduction system (Sutherland 1982). 
An unlabeled drawing of the SM can be clearly seen in Vesalius' texts (Vesalius 1543), but was first designated as the medullary stria by Wenzel and Wenzel (1812). Other terms over the years include the columna medullaris (Tarin 1750), the markiger Streisen (von Soemmerring 1791) and rené (reins) (Cruveilhier 1836). Previously considered part of the olfactory system due to its origins around the basal forebrain regions (Ramon y Cajal 1911), it is now well established that the SM is the primary afferent of the behavior modifying DDCS (Fakhoury et al. 2016a).

\section{Anatomy}

The stria medullaris first appears as a bilateral compact fascicle just posterior to the anterior commissure (Buchanan and Newton 1948). At this point, it is in contact with the fornix and stria terminalis as all three tracts converge around the anterior commissure. The SM runs caudally along the roof of the third ventricle, attached to the tela chordae (Faucette 1969) and arches dorsally over the thalamus. Coursing along the dorsomedial border of the thalamus, it forms a distinct horizontal ridge. In the $80 \%$ of individuals where an interthalamic adhesion is present (Allen and Gorski 1991; Carpenter 1991), it arches superior to this. The SM then descends caudally, its lateral fibers terminating in the habenula (Buchanan and Frazer 1937; Díaz et al. 2011). Cadaveric measurements place the diameter of the stria medullaris at between 1.5 and $2.5 \mathrm{~mm}$ across its length (Roddy et al. 2018), being widest caudally where it merges with the habenula. Both the SM and habenula can be seen as a combined rod-like structure on the posteromedial aspect of the thalamus, protruding into the lateral ventricle with an expansion towards the caudal thalamus. The SM white matter tract occupies $30 \%$ of the cross-sectional area of the habenula in humans. This SM-habenular interface is greatly enlarged in humans compared to that in rodents, with the SM taking up only $12 \%$ of the cross-sectional area in rats (Díaz et al. 2011).

In contrast to the lateral fibers, the medial SM fibers flex inwards towards the base of the pineal gland and cross to the opposite side. These terminate in the contralateral habenula (Buchanan and Frazer 1937; Naidich and Duvernoy 2009; Diaz et al. 2011). This decussation is known as the habenular commissure (Strotmann et al. 2014). Note that the nearby posterior commissure found in the inferior part of the pineal stalk is not anatomically or functionally part of the DDCS. The habenular commissure lying across the superior part of the pineal stalk together with the SM and habenulae form what is anatomically known as the habenular trigone (Strotmann et al. 2014). The lateral habenula also contributes to the habenular commissure in rats (Kim 2009); however, in humans, it is unclear what proportion of these commissural fibers derive from the SM, medial or lateral habenulae.
Three distinct groups of fibers are found in the human stria medullaris. Within the dorsolateral cross section of the tract travel fibers originating from the amygdala and striatal regions (Marburg 1944). Fibers from the basal forebrain areas lie dorsomedial and centrally within the SM; whereas, fibers that originate from the thalamus and hypothalamus are found ventrally. The course and relative position of these fibers remain unchanged through the SM as far as the habenula (Marburg 1944) and correspond with the general trend of lateral habenula fibers being more striatal in origin, and medial fibers being more basal forebrain/septal in origin.

The stria medullaris is also reported to have its own nucleus. A small compact group of cells thought to be the bed nucleus of the stria medullaris (BSM) was first reported in mice by Ramon y Cajal (1911). The nucleus, embedded among myelinated axons of the stria medullaris, is found caudally to the bed nucleus of the anterior commissure and between the stria medullaris and the fornix in rodents (Risold and Swanson 1995; Ramon y Cajal 1911). As a caudal extension of the septal region (Risold and Swanson 1995), the BSM is reported to contain small multipolar neurons and dense collaterals thought to arise from the fornix (Ramon y Cajal 1911). It has also been alluded to by others (Gurdjian 1927; Watson and Paxinos 1986; Jacobowitz and Palkovits 1974); however, borders have been difficult to identify (Risold and Swanson 1995) and connections of BSM itself have been difficult to establish, with only projections to the medial habenula identified thus far (Shinoda and Tohyama 1987).

Due to the thinness of the tract, the SM is often missed on standard resolution clinical MR imaging. As this tract has been identified as a potential therapeutic target for deep brain stimulation in depression and other neuropsychiatric diseases (Sartorius and Henn 2007), recent efforts have focused in localizing the trajectory of the tract for stereotactic neurosurgery using diffusion-weighted imaging (Kochanski et al. 2016; Roddy et al. 2018).

\section{Function}

In general, the SM gathers fibers from frontal, septal, striatal and hypothalamic areas and relays information from these areas through a single tract to the lateral and medial habenulae. Information is transmitted through the tract in a mostly unidirectional manner from the forebrain regions to the habenula. To date, however, there have been no fiber tracing or staining studies of the human SM.

The first-order inputs to the lateral habenula through the stria medullaris include the lateral preoptic area, the lateral hypothalamus, anterior hypothalamic nucleus, bed nucleus of the stria terminalis, the internal segment of the globus pallidus, substantia innominata and septum (Klemm 2004; Hikosaka et al. 2008). Second- and further-order inputs 
arise from medial, lateral and preoptic hypothalamic areas (Klemm 2004). The SM also inputs information from the nucleus of the diagonal band of Broca, lateral hypothalamus, lateral preoptic area and medial septal nuclei into the medial habenula (Akagi and Powell 1968; Klemm 2004). SM afferents are primarily cholinergic, glutamatergic and GABAergic, with primary GABAergic and cholinergic input into the habenula being supplied by the nucleus of the diagonal band of Broca via the SM (Viswanath et al. 2013; Klemm 2004). This was supported when bilateral transection of the SM in rodents induced a 50\% decrease in choline acetyltransferase, an enzyme responsible for acetylcholine synthesis, in the habenulae and the downstream interpeduncular nucleus, as well as a $65 \%$ decrease of glutamate decarboxylase in the habenula (Contestabile and Fonnum 1983).

The stria medullaris has recently been suggested as a therapeutic target for the treatment of depression and other neuropsychiatry diseases using deep brain stimulation (Sartorius and Henn 2007). Even though modulation of the lateral habenula is the proposed mechanism of this technique, electrode placement occurs at the caudal end of the SM, just beside the habenula. To date, two patients with intractable depression have shown marked improvement with modulation of the DDCS through SM stimulation (Sartorius et al. 2010; Kiening and Sartorius 2013).

The SM and habenula, although discrete structures, are essentially a functional unit and defining a function for the SM independent of the habenula is impossible. As such, the function of the SM will be integrated in the below section.

\section{Habenula}

(Latin; little reign) The trigonum habenulae is a small triangular eminence encompassed by the pineal gland, the posterior part of the stria medullaris and the adjacent part of the thalamus (Buchanan and Frazer 1937; Naidich and Duvernoy 2009). A slight swelling in this trigone indicates the position of the evolutionary conserved gray matter structure called the habenula (also known as the habenular complex, due to being composed of multiple nuclei) (Nolte 2002). It was first named by Meynert who described a small mass of gray matter on the posteromedial aspect of the thalamus (Meynert 1872). Originally considered anatomically and functionally the stalk of the adjacent pineal gland, it refers to two distinct groups of nuclei at the caudal end of the stria medullaris.

The habenula is the central component of the DDCS and has been well conserved throughout vertebrate evolution (Loonen et al. 2017). It acts as a hub, with limbic pathways traversing the stria medullaris to relay to the habenula prior to transmitting signals to brainstem modulatory areas (Carpenter 1991). As such, it is vital for integrating motor, cognitive, emotional and sensory processing within a single locus to influence motivational processes and value-based decision-making (Gardon et al. 2014). Recent studies highlighting the function of the habenula in encoding reward and aversive behavior have renewed the interest into this small structure.

\section{Anatomy}

The habenula, like many limbic structures, was initially believed to have primarily olfactory connections (Ramon y Cajal 1911); however, repeated studies have revealed its connections with a wide variety of regions across the brain (Rausch and Long 1971; Powell et al. 1965; Greatrex and Phillipson 1982; Gamble 1952). The habenula has both medial and lateral nuclei (see below). The literature strategy revealed that 135 studies have investigated habenular connections in diverse vertebrates from lizards to primates. Only one study to date has traced the connections of the human habenular complex (Marburg 1944). The results are presented in Table 1. Although some overlap, broadly speaking, motor, frontal, thalamic, hypothalamic, basal ganglia and associated areas (e.g., ventral tegmental area) project to the lateral habenula; whereas, septal and limbic associated areas (e.g., hippocampus) project to the medial habenula.

Although easily distinguishable as the thick caudal expansion of the combined SM-habenula rod-like structure that protrudes into the lateral ventricle, defining the rostral most boundaries of the habenula is challenging in gross dissections. This is because the SM tapers caudally and dorsally into the habenula. Regional microscopic differences in cellular distribution, however, allow the habenula to be distinguished from the white matter fibers of the SM and the multipolar cells of the adjacent thalamus (Marburg 1944; Díaz et al. 2011). The habenular width is approximately 5-9 mm across (Strotmann et al. 2014), as such the structure is difficult to visualize accurately using standard clinical MRI. However, using high-resolution magnetic resonance imaging (resolution $<1.5 \mathrm{~mm}^{3}$ ), it has recently been possible to determine the mean habenular volumes in a number of studies (Table 2a). Extrapolated mean values for left and right habenular complex volumes were found to be 21.9 $\mathrm{mm}^{3}\left(\mathrm{SD} \pm 6.5 \mathrm{~mm}^{3}\right)$ and $20.6 \mathrm{~mm}^{3}\left(\mathrm{SD} \pm 6.7 \mathrm{~mm}^{3}\right)$, respectively. A single post-mortem study has investigated habenular volumes (Ranft et al. 2010). This study suggested larger habenular volumes revealing lateral volumes of $27.57 \mathrm{~mm}$ $(\mathrm{SD} \pm 5.05 \mathrm{~mm})$ and $29.59 \mathrm{~mm}(\mathrm{SD} \pm 4.83 \mathrm{~mm})$ and medial volumes of $3.35 \mathrm{~mm}(\mathrm{SD} \pm 1.33 \mathrm{~mm})$ and $3.64 \mathrm{~mm}$ $(\mathrm{SD} \pm 0.97 \mathrm{~mm}$ ) for left and right sides, respectively. MRI resolution limitations, age variation and differences in measurement techniques between post-mortem and MRI studies could potentially account for the difference between the two methods of volume estimation. 
Table 1 Habenular inputs collated from previous tracing studies

\begin{tabular}{|c|c|c|}
\hline Area of input & Nucleus & References \\
\hline \multicolumn{3}{|l|}{ Cortical regions } \\
\hline Piriform cortex & Medial/lateral & $\begin{array}{l}\text { (Gurdjian 1925) (rat), (Carl Huber and Crosby 1929) (bird), } \\
\text { (Hines 1929) (platypus), (Loo 1931) (Opossum), (Young } \\
\text { 1936) (rabbit), (Humphrey 1936) (bat), (Marburg 1944) } \\
\text { (human), (Herrick 1948) (tiger salamander), (Gamble 1952) } \\
\text { (lizard), (Gamble 1956) (tortoise), (Ban 1962) (rat), (Powell } \\
\text { et al. 1965) (rat), (Millhouse 1969) (mouse), (Parent et al. } \\
\text { 1981) (rat, cat and monkey), (Kim and Lee 2012) (rat) }\end{array}$ \\
\hline Hippocampus & Medial & $\begin{array}{l}\text { (Hines 1929) (platypus), (Young 1936) (rabbit), (Humphrey } \\
\text { 1936) (bat), (Marburg 1944) (human) }\end{array}$ \\
\hline Amygdala & Medial/lateral & $\begin{array}{l}\text { "Nucleus Taenia" (Carl Huber and Crosby 1929) (bird), } \\
\text { (Young 1936) (rabbit), (Humphrey 1936) (bat), (Marburg } \\
\text { 1944) ( human), (Herrick 1948) (tiger salamander), (Gamble } \\
\text { 1952) (lizard), (Laursen 1955) (monkey), (Kusama and } \\
\text { Hagino 1961) (rabbit), (Mitchell 1963) (cats), (Cowan et al. } \\
\text { 1965) (rat), (Johnson 1965) (cat), (Millhouse 1969) (mouse), } \\
\text { (Leonard and Scott 1971) (rats), (Iwahori 1977) (cat), (Par- } \\
\text { ent et al. 1981) (rat, cat and monkey), (Li et al. 1993) (rat), } \\
\text { (Yetnikoff et al. 2015) (rat) }\end{array}$ \\
\hline Prelimbic cortex & Lateral & (Gamble 1952) (lizard), (Kim and Lee 2012) (rat) \\
\hline Infralimbic cortex & Lateral & (Kim and Lee 2012) (rat) \\
\hline Anterior cingulate cortex & Lateral & (Kim and Lee 2012) (rat) \\
\hline Anterior insular cortex & Lateral & $\begin{array}{l}\text { (Vertes 2002) (rat), (Vertes 2004) (rat), (Kim and Lee 2012) } \\
\text { (rat) }\end{array}$ \\
\hline
\end{tabular}

Basal forebrain

Septum undifferentiated

Medial septum

Lateral septum

Septofibrial nucleus

Triangular nucleus of septum

Precommissural septum
Medial/lateral
Medial/lateral

Medial/lateral

Medial

Medial

Medial
(Gurdjian 1925) (rat), (Carl Huber and Crosby 1929) (bird), (Humphrey 1936) (bat), (Nauta 1956) (Rat), (Nauta 1958) (cat), (Valenstein and Nauta 1959) (Rat, guinea pig, cat and monkey), (Guillery 1959) (Cat), (Cragg 1961) (rabbit, rat and cat), (Ban 1962) (rat), (Powell 1963) (rat), (Zyo 1963) (rabbit), (Mitchell 1963) (cats), (Johnson 1965) (cat), (Raisman 1966) (rat), (Powell 1966) (cat), (Powell 1968) (Rat, cat and monkey), (Mizuno et al. 1969) (cat), (Genton 1969) (mouse), (Price and Powell 1970) (Rat), (Smaha and Kaelber 1973) (opossum and cat), (Herkenham and Nauta 1977) (rat), (Iwahori 1977) (cat), (Meibach and Siegel 1977) (rat), (Swanson and Cowan 1979) (rat), (Gottesfeld and Jacobowitz 1979) (rat), (Parent et al. 1981) (rat, cat and monkey), (Hoogland 1982) (lizard), (Shinoda and Tohyama 1987) (rat), (Kawaja et al. 1990) (rat), "septal nucleus impar" (Díaz and Puelles 1992) (Lizard), (Li et al. 1993) (rat), (Felton et al. 1999) (rat), (Yetnikoff et al. 2015) (rat)

(Powell 1966) (cat), (Qin and Luo 2009) (mouse)

(Marburg 1944) (human), (Powell 1963) (rat), (Powell 1966) (cat), (Powell 1968) (Rat, cat and monkey), (Herkenham and Nauta 1977) (rat), (Gottesfeld and Jacobowitz 1979) (rat), (Sim and Joseph 1991) (rats), (Li et al. 1993) (rat), (Risold and Swanson 1997) (rat), (Yetnikoff et al. 2015) (rat)

(Powell 1966) (cat), (Powell 1968) (Rat, cat and monkey)

(Loo 1931) (Opossum), (Young 1936) (rabbit), (Herkenham and Nauta 1977) (rat), (Parent et al. 1981) (rat, cat and monkey), (Staines et al. 1988) (Rat), (Kawaja et al. 1990) (rat), (Li et al. 1993) (rat)

(Herkenham and Nauta 1977) (rat), (Staines et al. 1988) (Rat), (Kawaja et al. 1990) (rat), (Qin and Luo 2009) (mouse)

Medial/lateral/unspecified (Zyo 1963) (rabbit), (Johnson 1965) (cat), "rostral septum" (Powell 1966) (cat), "rostral septum" (Powell 1968) (Rat, cat and monkey) 
Table 1 (continued)

\begin{tabular}{|c|c|c|}
\hline Area of input & Nucleus & References \\
\hline Supracommissural septum & Medial & $\begin{array}{l}\text { (Nauta 1956) (Rat), (Herkenham and Nauta 1977) (rat), (Yañez } \\
\text { and Anadón 1996) (rainbow trout) }\end{array}$ \\
\hline Postcommissural septum & Medial & $\begin{array}{l}\text { (Cragg 1961) (rabbit, rat and cat), (Ban 1962) (rat), (Johnson } \\
\text { 1965) (cat), (Herkenham and Nauta 1977) (rat), (Parent et al. } \\
\text { 1981) (rat, cat and monkey), (Staines et al. 1988) (Rat) }\end{array}$ \\
\hline Diagonal band of Broca & Medial/lateral & $\begin{array}{l}\text { (Loo 1931) (Opossum), (Marburg 1944) (human), (Guillery } \\
\text { 1959) (Cat), (Powell 1966) (cat), (Price and Powell 1970) } \\
\text { (Rat), (Conrad and Pfaff 1976b) (rat), (Herkenham and Nauta } \\
\text { 1977) (rat), (Meibach and Siegel 1977) (rat), (Gottesfeld } \\
\text { and Jacobowitz 1979) (rat), (Parent et al. 1981) (rat, cat and } \\
\text { monkey), (Staines et al. 1988) (Rat), (Díaz and Puelles 1992) } \\
\text { (Lizard), (Li et al. 1993) (rat), (Qin and Luo 2009) (mouse), } \\
\text { (Yetnikoff et al. 2015) (rat) }\end{array}$ \\
\hline Susbtantia innominata & Lateral & $\begin{array}{l}\text { (Cragg 1961) (rabbit, rat and cat), (Kim et al. 1976) (mon- } \\
\text { key), "nucleus basalis" (Herkenham and Nauta 1977) (rat), } \\
\text { (Troiano and Siegel 1978a) (cat), (Parent et al. 1981) (rat, cat } \\
\text { and monkey) }\end{array}$ \\
\hline Nucleus accumbens & Unspecified & $\begin{array}{l}\text { "pars medialis of nucleus accumbens" (Loo 1931) (Opossum), } \\
\text { (Powell 1966) (cat), (Powell and Leman 1976) (monkey), } \\
\text { (Conrad and Pfaff 1976b) (Rat), (Herkenham and Nauta } \\
\text { 1977) (rat), (Troiano and Siegel 1978a) (cat), (Li et al. 1993) } \\
\text { (rat), (Felton et al. 1999) (rat), (Yetnikoff et al. 2015) (rat) }\end{array}$ \\
\hline Anterior olfactory nucleus & Unspecified & $\begin{array}{l}\text { (Gurdjian 1925) (rat), (Humphrey 1936) (bat), (Gamble } \\
\text { 1952) (lizard), (Gamble 1956) (tortoise), (Millhouse 1969) } \\
\text { (mouse), (Ferrer 1969) (hamster, (Heimer 1972) (rat) }\end{array}$ \\
\hline Olfactory tubercle & Unspecified & $\begin{array}{l}\text { (Loo 1931) (Opossum), (Morin 1950) (Guinea Pig), (Kusama } \\
\text { and Hagino 1961) (rabbit), (Ban 1962) (rat), (Millhouse } \\
\text { 1969) (mouse), (Heimer 1972) (rat), (Iwahori 1977) (cat), } \\
\text { (Parent et al. 1981) (rat, cat and monkey) }\end{array}$ \\
\hline Olfactory bulb & Unspecified & $\begin{array}{l}\text { (Ramon y Cajal 1911) (vertebrates), (Herrick 1948) (tiger } \\
\text { salamander) }\end{array}$ \\
\hline \multicolumn{3}{|l|}{ Central white matter nuclei } \\
\hline Nucleus of posterior pallial commissure & Medial & (Díaz and Puelles 1992) (Lizard) \\
\hline Bed nucleus of anterior commissure & Medial/lateral & $\begin{array}{l}\text { (Carl Huber and Crosby 1929) (bird), Herrick } 1948 \text { (tiger } \\
\text { salamander), (Staines et al. 1988) (Rat), (Díaz and Puelles } \\
\text { 1992) (Lizard) }\end{array}$ \\
\hline Bed nucleus of stria terminalis & Medial/lateral & $\begin{array}{l}\text { (Marburg 1944) (human), (Cragg 1961) (Rabbit), (Conrad } \\
\text { and Pfaff 1976b) (Albino Rats), (Swanson and Cowan 1979) } \\
\text { (rat), (Parent et al. 1981) (rat, cat and monkey), (Weller and } \\
\text { Smith 1982) (rat), (Staines et al. 1988) (Rat), (Díaz and } \\
\text { Puelles 1992) (Lizard), (Li et al. 1993) (rat), (Dong and } \\
\text { Swanson 2006) (rats), (Yetnikoff et al. 2015) (rat) }\end{array}$ \\
\hline \multicolumn{3}{|l|}{ Basal Ganglia } \\
\hline Globus pallidus externa & Lateral/unspecified & $\begin{array}{l}\text { (Ranson and Ranson 1941) (monkey), (Mitchell 1963) (cats), } \\
\text { (Nauta and Mehler 1966) (monkey), (Kim et al. 1976) } \\
\text { (monkey), (Gottesfeld et al. 1977) (rat), (Herkenham and } \\
\text { Nauta 1977) (Rat), (Parent et al. 1981) (rat, cat and monkey), } \\
\text { (Hoogland 1982) (lizard), (Araki et al. 1984) (rat), (Li et al. } \\
\text { 1993) (rat), (Felton et al. 1999) (rat) }\end{array}$ \\
\hline
\end{tabular}


Table 1 (continued)

\begin{tabular}{ll}
\hline Area of input & Nucleus \\
\hline Globus Pallidus interna (Entopeduncular Nucleus) & Lateral/unspecified
\end{tabular}

Ventral Pallidum

Unspecified

Thalamic nuclei

Thalamus undifferentiated

Medial/lateral

Lateral

Anterior Group

Unspecified

Anterodorsal nucleus

Anteroventral nucleus

Lateral

Paramedian thalamus

Medial

Reticular nucleus

Lateral

Epithalamus

Hypothalamus

Hypothalamus undifferentiated

Lateral nucleus
Medial/lateral

Lateral
References

(Mitchell 1963) (cat), (Herrick 1948) (tiger salamander), (Nauta and Mehler 1966) (Monkey), (Kim et al. 1976) (monkey), (Iwahori 1977) (cat), (Herkenham and Nauta 1977) (rat), (Gottesfeld et al. 1977) (rat), (Nagy et al. 1978) (rat), (Filion and Harnois 1978) (cat), (Carter and Fibiger 1978) (rat), (Larsen and Sutin 1978) (cat), (Parent 1979) (squirrel monkey), (Larsen and McBride 1979) (cat), (Parent et al. 1981) (rat, cat and monkey), (Van Der Kooy and Carter 1981) (rat), (McBride 1981) (cat), (Hoogland 1982) (lizard), (Vincent et al. 1982) (rat), (Garland and Mogenson 1983) (rats), (Araki et al. 1984) (Rat), (Vincent and Brown 1986) (Rat), (Shinoda and Tohyama 1987) (rat), (Hazrati and Parent 1991) (squirrel monkey), (Moriizumi and Hattori 1992) (rat), "lobus subhippocampus" (Yañez and Anadon 1994) (Lamprey), "rostral thalamus" (Yañez and Anadón 1996) (rainbow trout), (Kha et al. 2000) (rats), (Parent et al. 2001) (monkey), (Folgueira et al. 2004) (rainbow trout), (Wallace et al. 2017) (mice)

(Kim et al. 1976) (monkey), (Herkenham and Nauta 1977) (rat), (Troiano and Siegel 1978b) (cat), (Parent 1979) (squirrel monkey), (Groenewegen et al. 1993) (rat), (Li et al. 1993) (rat), (Haber et al. 1993) (monkey), (Zahm et al. 1996) (rats), (Hendricks and Jesuthasan 2007) (Zebrafish), (Tripathi et al. 2013) (rat)

(Hines 1929) (platypus), "dorsal thalamus" (Herrick 1948) (tiger salamander), (Mitchell 1963) (cats), (Smaha and Kaelber 1973) (opossum and cat), "dorsal thalamus" (Díaz and Puelles 1992) (Lizard), "thalamic eminence" (Krug et al. 1993) (Axolotl-fish), "thalamic eminence" (Hendricks and Jesuthasan 2007) (Zebrafish)

(Cragg 1961) (rabbit), (Smaha and Kaelber 1973) (opossum and cat)

(Yañez and Anadon 1994) (Lamprey)

(Yetnikoff et al. 2015) (rat)

(Cragg 1961) (rabbit), (Hoogland 1982) (lizard)

(Felton et al. 1999) (rat)

"Pineal gland" (Yañez and Anadón 1996) (rainbow trout)

(Carl Huber and Crosby 1929) (bird), (Humphrey 1936) (bat), (Marburg 1944) (human), (Mitchell 1963) (cats), (Zyo 1963) (rabbit), (Parent et al. 1981) (rat, cat and monkey), (Li et al. 1993) (rat), (Yañez and Anadón 1996) (rainbow trout), (Felton et al. 1999) (rat), (Yetnikoff et al. 2015) (rat)

(Nauta 1958) (cat), (Kusama and Hagino 1961) (rabbit), (Zyo 1963) (rabbit), (Wolf and Sutin 1966) (Rat), (Mizuno et al. 1969) (cat), (Smaha and Kaelber 1973) (opossum and cat), (Troiano and Siegel 1975) (cat), (Swanson 1976) (rat), (Iwahori 1977) (cat), (Herkenham and Nauta 1977) (Rat), (Parent 1979) monkey), (Saper et al. 1979) (rat), (McBride 1981) (cat), (Parent et al. 1981) (rat, cat and monkey), (Berk and Finkelstein 1982) (Rat), (Araki et al. 1984) (Rat), (Shinoda and Tohyama 1987) (rat), (Díaz and Puelles 1992) (Lizard), (Li et al. 1993) (rat), (Yañez and Anadón 1996) (rainbow trout), (Felton et al. 1999) (rat), (Kowski et al. 2008) (rat), (Hahn and Swanson 2010) (rat), (Hahn and Swanson 2012) (rat), (Yetnikoff et al. 2015) (rat)

(Li et al. 1993) (rat) 
Table 1 (continued)

\begin{tabular}{|c|c|c|}
\hline Area of input & Nucleus & References \\
\hline Paraventricular nucleus & Unspecified & $\begin{array}{l}\text { "magnocellular nucleus" (Loo 1931) (Opossum), (Smaha and } \\
\text { Kaelber 1973) (opossum and cat), (von Bartheld and Meyer } \\
\text { 1990) (lungfish), (Li et al. 1993) (rat) }\end{array}$ \\
\hline Suprachiasmatic nucleus & Lateral & (Buijs 1978) (rats), (Sofroniew et al. 1981) (rats) \\
\hline Ventromedial nucleus & Lateral & (Li et al. 1993) (rat), (Yetnikoff et al. 2015) (rat) \\
\hline Anterior nucleus & Lateral & $\begin{array}{l}\text { (Conrad and Pfaff 1976b) (Albino Rats), (McBride 1981) (cat), } \\
\text { (Parent et al. 1981) (rat, cat and monkey), (Li et al. 1993) } \\
\text { (rat), (Risold et al. 1994) (rat) }\end{array}$ \\
\hline Supraoptic nucleus & Unspecified & (Humphrey 1936) (bat) \\
\hline Posterior nucleus & Lateral & (McBride 1981) (cat) \\
\hline Preoptic hypothalamus undifferentiated & Medial/lateral & $\begin{array}{l}\text { (Gurdjian 1925) (rat), (Gurdjian 1927) (rat), (Hines 1929) } \\
\text { (platypus), (Carl Huber and Crosby 1929) (bird), (Loo } \\
\text { 1931) (Opossum), (Humphrey 1936) (bat), (Marburg 1944) } \\
\text { (human), (Herrick 1948) (tiger salamander), (Zyo 1963) (rab- } \\
\text { bit), (Smaha and Kaelber 1973) (opossum and cat), (Herken- } \\
\text { ham and Nauta 1977) (Rat), (McBride 1981) (cat), (Li et al. } \\
\text { 1993) (rat), (Yañez and Anadón 1996) (rainbow trout) }\end{array}$ \\
\hline Medial preoptic nucleus & Lateral & $\begin{array}{l}\text { (Gurdjian 1925) (rat), (Young 1936) (rabbit), (Marburg 1944) } \\
\text { (human), (Conrad and Pfaff 1976a) (Albino Rat), (Anderson } \\
\text { and Shen 1980) (guinea pig), (Li et al. 1993) (rat), (Yetnikoff } \\
\text { et al. 2015) (rat) }\end{array}$ \\
\hline Lateral preoptic nucleus & Lateral & $\begin{array}{l}\text { (Young 1936) (rabbit), (Nauta 1958) (cat), (Cragg 1961) (Rab- } \\
\text { bit), (Kusama and Hagino 1961) (rabbit), (Zyo 1963) (rab- } \\
\text { bit), (Cowan et al. 1965) (rat), (Wolf and Sutin 1966) (rat), } \\
\text { (Mizuno et al. 1969) (cat), (Troiano and Siegel 1975) (cat), } \\
\text { (Swanson 1976) (rat), (Iwahori 1977) (cat), (Herkenham and } \\
\text { Nauta 1977) (rat), (Troiano and Siegel 1978b) (cat), (Parent } \\
\text { et al. 1981) (rat, cat and monkey), (Garland and Mogenson } \\
\text { 1983) (rats), (Díaz and Puelles 1992) (Lizard), (Li et al. } \\
\text { 1993) (rat), (Felton et al. 1999) (rat), (Kowski et al. 2008) } \\
\text { (Rat), (Yetnikoff et al. 2015) (rat) }\end{array}$ \\
\hline Mammillary bodies & Lateral & $\begin{array}{l}\text { (Parent et al. 1981) (rat, cat and monkey), (Díaz and Puelles } \\
\text { 1992) (Lizard) }\end{array}$ \\
\hline Premammillary nucleus & Lateral & (Li et al. 1993) (rat) \\
\hline \multicolumn{3}{|l|}{ Brainstem } \\
\hline Tectum & Unspecified & (Marburg 1944) (human), (Herrick 1948) (tiger salamander) \\
\hline Tegmentum undifferentiated & Unspecified & (Hoogland 1982) (lizard) \\
\hline Laterodorsal tegmental nucleus & Medial/lateral/unspecified & $\begin{array}{l}\text { "Nucleus isthmi" (Hoogland 1982) (lizard), (Cornwall et al. } \\
\text { 1990) (rat), (Li et al. 1993) (rat), (Yetnikoff et al. 2015) (rat) }\end{array}$ \\
\hline Dorsal tegmental area & Lateral & (Goto et al. 2001) (rat), (Olucha-Bordonau et al. 2003) (rat) \\
\hline Ventral tegmental area & Medial/lateral & $\begin{array}{l}\text { (Lindvall and Björklund 1974) (rat), (Kizer et al. 1976) (rat),), } \\
\text { (Herkenham and Nauta 1977) (rat), "ventral tegmental pars } \\
\text { lateralis" (Simon et al. 1979) (rat), (Beckstead et al. 1979) } \\
\text { (rat), "ventral tegmental interfascicular nucleus" and "ventral } \\
\text { tegmental median paranigral" (Phillipson and Griffith 1980) } \\
\text { (rat), (Parent et al. 1981) (rat, cat and monkey), (Phillipson } \\
\text { and Pycock 1982) (rat), (Swanson 1982) (rat), (Skagerberg } \\
\text { et al. 1984) (rat), (Díaz and Puelles 1992) (Lizard), (Li et al. } \\
\text { 1993) (rat), (Gruber et al. 2007) (rat), (Yetnikoff et al. 2015) } \\
\text { (rat) }\end{array}$ \\
\hline Pretectal area & Unspecified & (Herrick 1948) (tiger salamander) \\
\hline Periaqueductal gray & Lateral & (Li et al. 1993) (rat), (Yetnikoff et al. 2015) (rat) \\
\hline Locus coeruleus & Unspecified & $\begin{array}{l}\text { (Hoogland 1982) (lizard), (Gottesfeld 1983) (rat), (Yañez and } \\
\text { Anadón 1996) (rainbow trout), (Gruber et al. 2007) (rat), } \\
\text { (Yetnikoff et al. 2015) (rat) }\end{array}$ \\
\hline Substantia nigra compacta & Lateral & $\begin{array}{l}\text { (Kizer et al. 1976) (rat), (Li et al. 1993) (rat), (Yetnikoff et al. } \\
\text { 2015) (rat) }\end{array}$ \\
\hline
\end{tabular}


Table 1 (continued)

\begin{tabular}{|c|c|c|}
\hline Area of input & Nucleus & References \\
\hline Interpeduncular nucleus & Lateral & $\begin{array}{l}\text { (Massopust Jr and Thompson 1962) (rats and cats), (Mitchell } \\
\text { 1963) (cats) }\end{array}$ \\
\hline Raphe Nuclei undifferentiated & Lateral & $\begin{array}{l}\text { (Herkenham and Nauta 1977) (rat), (Moore et al. 1978) (rat), } \\
\text { (McBride 1981) (cat), (Li et al. 1993) (rat),(Morin and } \\
\text { Meyer-Bernstein 1999) (hamster), (Felton et al. 1999) (rat), } \\
\text { (Yetnikoff et al. 2015) (rat), (Muzerelle et al. 2016) (mouse) }\end{array}$ \\
\hline Raphe nuclei dorsal & Medial/lateral & $\begin{array}{l}\text { (Conrad et al. 1974) (rat), (Pierce et al. 1976) (cat), (Azmitia } \\
\text { and Segal 1978) (rat), (Li et al. 1993) (rat) }\end{array}$ \\
\hline Raphe nuclei median & Medial/lateral & $\begin{array}{l}\text { (Conrad et al. 1974) (rat), "superior raphe" (Bobillier et al. } \\
\text { 1975) (cat), "superior raphe" (Bobillier et al. 1976) (cat), } \\
\text { (Herkenham and Nauta 1977) (rat), (Azmitia and Segal } \\
\text { 1978) (rat), "superior raphe" (Bobillier et al. 1979) (rat), } \\
\text { "superior raphe" (Hoogland 1982) (lizard), (Hallanger et al. } \\
\text { 1987) (rat), (Vertes and Martin 1988) (rat), (Vertes et al. } \\
\text { 1999) (rat), (Li et al. 1993) (rat), (Yetnikoff et al. 2015) (rat) }\end{array}$ \\
\hline Interfascicular nucleus & Lateral & (Li et al. 1993) (rat) \\
\hline Superior Cervical ganglion & Medial & $\begin{array}{l}\text { (Björklund et al. 1972) (rat), (Lindvall and Björklund 1974) } \\
\text { (rat), (Gottesfeld 1983) (rat) }\end{array}$ \\
\hline
\end{tabular}

Literature review methods detailed in the text

Table 2 (A and B) Summary of habenular volumes given in $\mathrm{mm}^{3}$ in the current literature

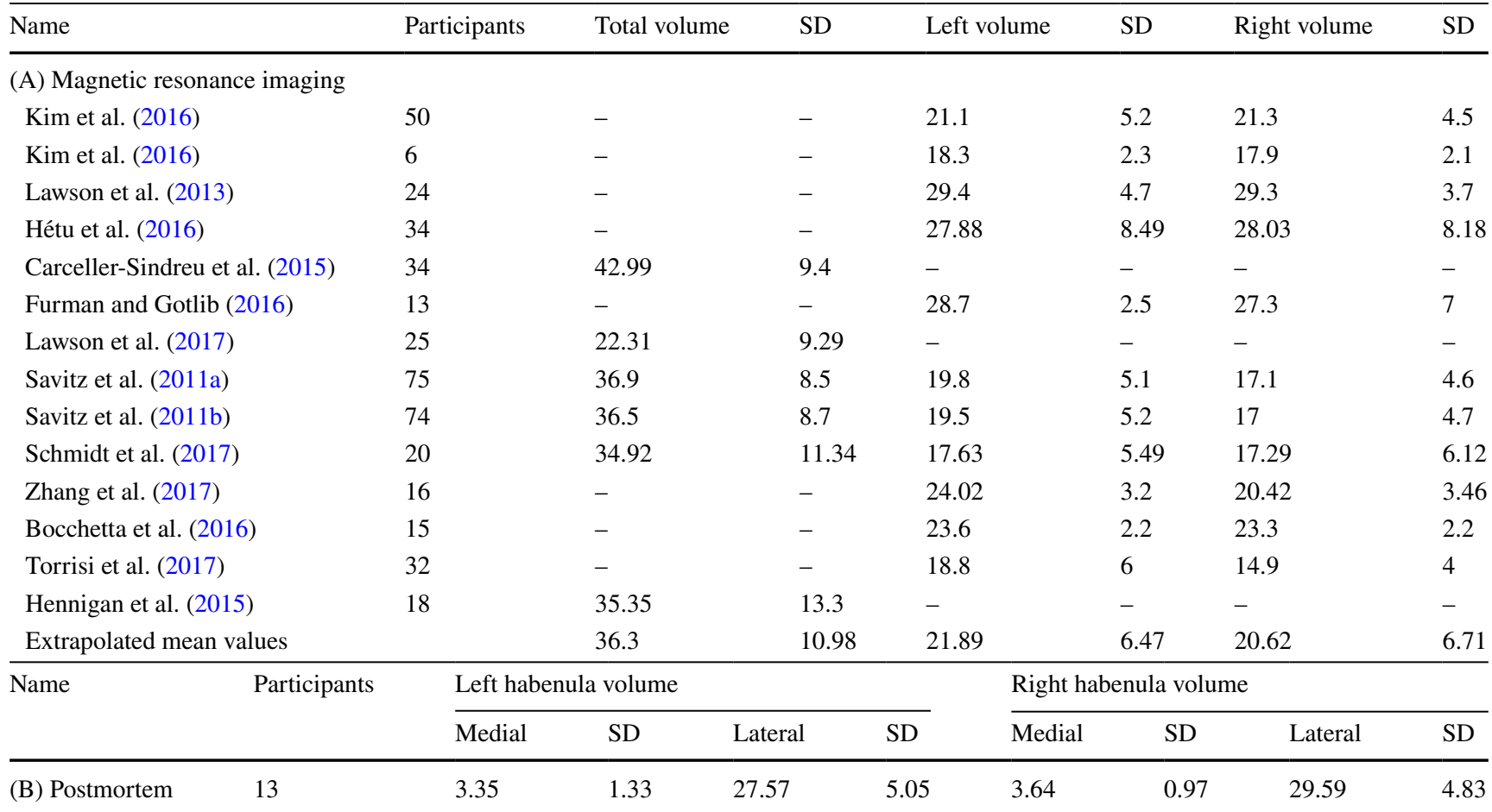

(A) Whole, lateral and medial mean habenular volumes extrapolated from 14 high resolution magnetic resonance imaging studies with a total of 356 subjects. See text for further details. (B) Postmortem medial and lateral habenular volumes in 13 participants are reported. SD, standard deviation.

In mammals, the habenula comprises of two functionally segregated nuclei, the medial habenula $(\mathrm{MHb})$ and lateral habenula $(\mathrm{LHb})$. The lateral is the larger of the two and is further divided into medial and lateral portions in humans and other mammals (Torrisi et al. 2017; Fore et al. 2017; Carpenter 1991). These nuclei share many similar sources of 
afferent inputs and efferent nuclei but have distinct anatomy and connectivity within brain networks (Fakhoury 2017; Bianco and Wilson 2009; Gardon et al. 2014).

\section{Medial habenula}

The medial habenula is the smaller and least studied of the two nuclei (Viswanath et al. 2013; Iwahori 1977; Ramon y Cajal 1911). It borders the wall of the third ventricle and contains a more homogeneously densely packed array of cells when compared to the $\mathrm{LHb}$. MHb volumes in human postmortem studies are reported in Table $2 \mathrm{~b}$. The human MHb can be subdivided into five subnuclei, which can be most easily distinguished from each other in terms of cell packing density, as opposed to cell type. This is because most cells in each of the five nuclei are small round cells (Table 3) (Diaz et al. 2011). These cells have a soma diameter of 8.85 .

The medial habenula is richly innervated from multiple neuronal types. In animals, the predominant innervations to the $\mathrm{MHb}$ come from septal regions and are largely inhibitory through the action of GABAergic neurons (Torrisi et al. 2017; Benarroch 2015; Batalla et al. 2017). Indeed, the medial habenula contains some of the highest concentration of GABA-B receptors in the rat brain (Wang et al. 2006; Bischoff et al. 1999; Durkin et al. 1999; Charles et al. 2001). However, other afferents terminate as cholinergic (Contestabile and Fonnum 1983), substance P (Contestabile et al. 1987) and glutamate (Qin and Luo 2009). Additionally, the medial habenula abundantly expresses nicotinic

Table 3 Summary of reported sub-nucleic histological characteristics of the human habenula

\begin{tabular}{|c|c|c|c|c|c|}
\hline Subnuclei & Cell shape and size & Cellular distribution & Fiber distribution & Cell packing & References \\
\hline \multicolumn{6}{|c|}{ Undifferentiated Habenula } \\
\hline Ventromedial & $\begin{array}{l}\text { Very small celled, spindle } \\
\text { shaped }\end{array}$ & - & - & Densely packed & Marburg (1944) \\
\hline Medial & $\begin{array}{l}\text { Small celled, larger and } \\
\text { fewer cells, spindle } \\
\text { shaped, }\end{array}$ & - & - & Loosely packed & Marburg (1944) \\
\hline Dorsomedial & $\begin{array}{l}\text { Small celled, larger and } \\
\text { fewer cells, spindle } \\
\text { shaped }\end{array}$ & - & - & Loosely packed & Marburg (1944) \\
\hline Dorsolateral & $\begin{array}{l}\text { Small spindle shaped and } \\
\text { medium sized cells, } \\
\text { polygonal, containing } \\
\text { well-developed nuclei } \\
\text { and trigoid bodies }\end{array}$ & - & - & - & Marburg (1944) \\
\hline Lateral & Large celled & - & - & - & Marburg (1944) \\
\hline \multicolumn{6}{|l|}{ Medial habenula } \\
\hline Dorsal & Small round & $\begin{array}{l}\text { Heterogenous with myeli- } \\
\text { nated fibers }\end{array}$ & $\begin{array}{l}\text { Few fibers, forming } \\
\text { bundles }\end{array}$ & Intermediately packed & Diaz et al. (2011) \\
\hline Medial & Small round & Homogenous & Few fibers and very thin & Loosely packed & Diaz et al. (2011) \\
\hline Intermediate & Small round & Homogenous & $\begin{array}{l}\text { Few fibers, forming a } \\
\text { loose network }\end{array}$ & Densely packed & Diaz et al. (2011) \\
\hline Lateral & Small round & Homogenous & Few fibers and very thin & Densely packed & Diaz et al. (2011) \\
\hline Ventral & $\begin{array}{l}\text { Small round, medium } \\
\text { round }\end{array}$ & Homogenous & $\begin{array}{l}\text { Thin, with fibers emerging } \\
\text { as fasciculus retroflexus }\end{array}$ & Densely packed & Diaz et al. (2011) \\
\hline \multicolumn{6}{|l|}{ Lateral habenula } \\
\hline Dorsal & All cell types & $\begin{array}{l}\text { Heterogenous with myeli- } \\
\text { nated fibers }\end{array}$ & $\begin{array}{l}\text { Many fibers, forming thick } \\
\text { bundles }\end{array}$ & Loosely packed & Diaz et al. (2011) \\
\hline Medial & $\begin{array}{l}\text { Small round, medium } \\
\text { round }\end{array}$ & $\begin{array}{l}\text { Heterogenous, with occa- } \\
\text { sional clumping }\end{array}$ & $\begin{array}{l}\text { Very thin, reticulated } \\
\text { pattern }\end{array}$ & Loosely packed & Diaz et al. (2011) \\
\hline Intermediate & $\begin{array}{l}\text { Small round, medium } \\
\text { elongated, medium } \\
\text { multipolar }\end{array}$ & Heterogenous & $\begin{array}{l}\text { Few fibers and very thin, } \\
\text { forming reticulated } \\
\text { pattern }\end{array}$ & Loosely packed & Diaz et al. (2011) \\
\hline Lateral & $\begin{array}{l}\text { Small round, small large } \\
\text { multipolar }\end{array}$ & $\begin{array}{l}\text { Heterogenous with clump- } \\
\text { ing }\end{array}$ & $\begin{array}{l}\text { Many fibers, forming a } \\
\text { reticulated pattern }\end{array}$ & Intermediately packed & Diaz et al. (2011) \\
\hline Ventral & $\begin{array}{l}\text { Small round, medium } \\
\text { round and a few medium } \\
\text { elongated }\end{array}$ & Heterogenous & $\begin{array}{l}\text { Many fibers, thin, with } \\
\text { fibers emerging as fas- } \\
\text { ciculus retroflexus }\end{array}$ & Intermediately packed & (Diaz et al. 2011) \\
\hline
\end{tabular}


acetylcholine receptors (Sheffield et al. 2000). Monoamine inputs such as serotonin (Herkenham and Nauta 1977), noradrenaline (Gottesfeld 1983) and dopamine (Phillipson and Pycock 1982) also target the MHb through feedback projections from the midbrain.

The MHb outputs extend through the core of the fasciculus retroflexus to the midbrain and hindbrain. MHb neurons are predominantly excitatory, releasing the neurotransmitters acetylcholine, substance $\mathrm{P}$ and glutamate (Aizawa et al. 2012; Viswanath et al. 2013). These neurons primarily target the serotonergic neurons of the median raphe nuclei directly or indirectly via interpeduncular nucleus (IPN) (Koppensteiner et al. 2016; Contestabile et al. 1987) and noradrenergic inputs from the locus coeruleus (Benarroch 2015; Díaz et al. 2011; Fakhoury 2017; Bianco and Wilson 2009). The IPN also provides feedback projections to brain areas that target the MHb such as the septal regions through the medial forebrain bundle (Hayakawa et al. 1981) as well as the $\mathrm{MHb}$ itself (Benarroch 2015). Of note, there are two principal subnuclei that can be identified using the transmitter acetylcholine in the ventral $\mathrm{MHb}$ and the expression of substance $\mathrm{P}$ in the dorsal MHb (Contestabile et al. 1987; Hsu et al. 2016). While they both project to the IPN, they innervate distinct structures within it (Hsu et al. 2014).

\section{Lateral habenula}

The lateral habenula lies between the medial habenula and the thalamus. It is considerably larger than the MHb in most species and can be distinguished from the smaller structure microscopically by having a much less compacted and more heterogeneous cell population overall (Díaz et al. 2011). The human $\mathrm{LHb}$ is greatly expanded compared to the MHb, with the LHb being about 8 times bigger than the MHb (Table 2). This suggests an increased influence of limbic and striatal afferents upon the DCSS in humans. The LHb can be further subdivided into medial $\mathrm{LHb}$ and lateral $\mathrm{LHb}$ subdomains. Five separate nuclei are observed in the LHb and these can be distinguished from each other in terms of the heterogenous cell shapes and sizes seen in the LHb as opposed to the packing density distinctions seen in the MHb (Table 3) (Diaz et al. 2011). The cellular organization within the $\mathrm{LHb}$ shows a larger degree of variability among individuals than the MHb and the distinction between nuclei is less precise; however, the broad overall cellular organization within the LHb is medial parvocellular and lateral magnocellular regions (Marburg 1944).

The LHb innervations are generally more dispersed and heterogeneous than $\mathrm{MHb}$ afferents. Primary excitatory glutamatergic innervations originate from the prefrontal cortex, basal ganglia and lateral hypothalamus (Baker et al. 2016; Batalla et al. 2017). The majority of the fastmediating excitatory transmission identified in the LHb is through the AMPA-type glutamate receptors (Meye et al. 2013; Li et al. 2013). The $\mathrm{LHb}$ receives strong inhibitory GABAergic inputs arising through long-range projections from areas such as the nucleus accumbens, diagonal band of Broca, the lateral preoptic area, substantia innominate and the ventral pallidum (Meye et al. 2013; Benarroch 2015). The medial globus pallidus GABA projections preferentially innervate the lateral portion of the $\mathrm{LHb}$, whilst the diagonal band of Broca and lateral preoptic areas primarily target the medial portion (Herkenham and Nauta 1977). Additionally, midbrain and hindbrain targets of the LHb provide dopaminergic (ventral tegmental area), noradrenergic (locus coeruleus) and serotonergic (median raphe nucleus) feedback projections, suggesting that dopamine, noradrenaline and serotonin have modulatory effects on the LHb (Meye et al. 2013; Benarroch 2015). Other inputs arise from the suprachiasmatic nucleus, providing $\mathrm{GABA}$ /vasopressinergic innervations into the LHb (Benarroch 2015).

In spite of sharing a singular output tract, there appears to be little overlap between efferents and function of the $\mathrm{MHb}$ and LHb (Quina et al. 2015). Through the external mantle of the FR, the LHb projects to multiple monoaminergic mesencephalic areas such as the ventral tegmental area (VTA) and periaqueductal gray and rhombencephalic areas such as raphe nucleus and locus coeruleus. In rodents, there exists a structure called the rostromedial tegmental nucleus (RMTg) which is essentially an inhibitory tail (Kaufling et al. 2009) of the VTA (Holstege 2009). It has been shown that most glutamatergic axons from the LHb primarily target the GABAergic neurons of the VTA and RMTg, leading to an overall inhibitory effect (Brinschwitz et al. 2010). RMTg in particular exhibits a high density of habenular efferents, despite only accounting for less than $20 \%$ of the total outputs of the LHb to the hindbrain (Quina et al. 2015). The RMTg inhibits the nearby dopaminergic neurons of the VTA and substantia nigra pars compacta $(\mathrm{SNc})$ directly and the serotonergic neurons of the raphe nuclei indirectly (Díaz et al. 2011; Fakhoury 2017). This intermediary structure has not been isolated as yet in human post-mortem studies (Hétu et al. 2016). There are also direct bilateral innervations of the $\mathrm{LHb}$ to the VTA, with electrical stimulation of the $\mathrm{LHb}$ causing direct orthodromic reduction of dopaminergic tone in the VTA and its axons to the nucleus accumbens ( $\mathrm{Ji}$ and Shepard 2007; Christoph et al. 1986). Similarly, lesioning the LHb causes an increase in serotoninergic activity in the dorsal raphe by activating the local GABAergic neurons (Varga et al. 2003; Amat et al. 2001) Retrograde studies have also identified the median raphe, caudal dorsal raphe, and pontine central gray as LHb targets (Quina et al. 2015). $\mathrm{LHb}$ efferents also feedback to the lateral hypothalamic area, septum and several thalamus nuclei (Benarroch 2015; Batalla et al. 2017). 


\section{Function}

Despite overlapping sources of connectivity, the medial and lateral habenula appear to represent largely distinct functional subcircuits within the DDCS. The MHb regulates inhibitory controls, cognition-dependent executive functions and place aversion learning (Gardon et al. 2014). The MHb also has a role with respect to misery-fleeing behavior, stress responses, neural control of sleep and analgesia (Loonen et al. 2017; Díaz et al. 2011). These functions correspond with the inputs from the pleasure and motivational centers of the forebrain.

Although the MHb has remained largely unstudied, it is proposed that two subnuclei, the ventral and dorsal subnuclei, are largely responsible for its functions. The ventral $\mathrm{MHb}$, containing cholinergic neurons, has been associated with the somatic symptoms of nicotine withdrawal by inhibiting serotonin and dopamine within the IPN (Zhao-Shea et al. 2013; Lee et al. 2019). Whereas, the substance $P$ containing dorsal $\mathrm{MHb}$ is implicated in fear responses (Lee et al. 2019). A study in rodents demonstrated a reduction in activity of the dorsal medial habenula with fear conditioning. The authors suggested that diminished MHb may result due to interference with medial raphe nucleus activity, including hippocampal ripple activity and fear memory consolidation (Koppensteiner et al. 2016).

The LHb is involved in rewards signals, aversion and behavioral avoidance (Gardon et al. 2014). These functions were first suggested following studies which revealed that the habenula was involved in reward through brain stimulation (Boyd and Celso 1970). With the LHb long considered as the 'missing link' in the mechanisms of reward pathways (Brinschwitz et al. 2010), efforts have been made to further uncover its exact functionality and underlying mechanisms. Studies in the lamprey show that when there is rewarding behavior, the $\mathrm{LHb}$ promotes the behaviour by intensifying stimulation of the phylogenetic homolog of the VTA (Loonen et al. 2017). However, when the reward is smaller than expected or absent, the behavior is inhibited by affecting the VTA equivalent. Furthermore, the habenula has been implicated in circadian behaviour due to its connections with the nearby pineal and suprachiasmatic nucleus, with both $\mathrm{MHb}$ and in particular LHb cells showing increased firing during the day than night (Zhao and Rusak 2005).

Peptidomic analysis has identified a total of 262 and 177 neuropeptides in the medial and lateral habenula, respectively, with 126 present in both regions (Yang et al. 2018). One of the peptides identified was somatostatin, often associated with chronic stress. Previously, stressed rats were reported to have significantly upregulated somatostatin receptors on the medial habenula (Faron-Górecka et al. 2016). Additionally, multiple pain-related peptides (nociception, pro-enkephalin-A, pro-dynorphin-related prohormones) were also detected (Yang et al. 2018). These peptides are involved in pain signaling mechanisms through the binding of opioid and nociception receptors. Such findings are consistent with current literature on habenular involvement in pain and analgesia (Shelton et al. 2012a; Levins et al. 2019).

Significant findings from these extensive studies conducted in animals have led to investigations of the habenula in humans. All studies investigating the function of the human habenula have taken place using magnetic resonance imaging. Imaging the habenula suffers from resolution issues due to the size and shape of the structure and the resolution of standard functional MRI imaging. Also, due to position and shape, imaging this structure is further complicated as a result of its proximity to the third ventricle and subsequent partial volume effects. As such functional imaging studies of this structure are small in number and limited in scope. However, the habenula has been implicated in processing aversive stimuli (Lawson et al. 2014; Hennigan et al. 2015)and error detection (Ullsperger and von Cramon 2003; Li et al. 2008; Salas et al. 2010; Ide and Li 2011). The human habenula has been found to be functionally coupled with the insula, septum, thalamus, striatum, pons, substantia nigra/ventral tegmental area, periaqueductal gray, stria terminalis and parahippocampal regions (Hétu et al. 2016; Torrisi et al. 2017). The structure has also been functionally linked with pain responses (Shelton et al. 2012b) subclinical depressive symptoms (Ely et al. 2016), and anxious thoughts (Najafi et al. 2017) in normal individuals. A promising new field of clinical research examining the habenula is underway with many studies implicating this diminutive structure in depression (Lawson et al. 2017; Schmidt et al. 2017), anxiety (Savitz et al. 2011a), schizophrenia (Shepard et al. 2006), frontotemporal dementia (Bocchetta et al. 2016), addictions (Curtis et al. 2017; Rose et al. 2017) and chronic pain (Erpelding et al. 2014), cancer-associated weight loss (Maldonado et al. 2018) and Parkinson's disease (Markovic et al. 2017).

\section{Habenular asymmetry}

Many species exhibit asymmetries in size, anatomical organization and function (Schmidt and Pasterkamp 2017; Bianco and Wilson 2009; Concha and Ahumada-Galleguillos 2016; Dreosti et al. 2014; Ichijo et al. 2015). The significance of this is unknown; however, an intriguing functional impact of left-right habenular differences has been found in zebrafish (Dreosti et al. 2014; Krishnan et al. 2014; Ichijo et al. 2017; Halpern et al. 2003) and in mice (Ichijo et al. 2015, 2017). In Zebrafish, lateralization appears more structurally fixed (Ichijo et al. 2017), with habenular neurons shown to respond to light more frequently on the left; whereas, responses to odor were more likely to be found in the right habenula (Dreosti et al. 2014). Meanwhile, in 
mice $\mathrm{LHb}$ lateralization appears more functionally flexible and occurs during postnatal development and in response to water-immersion restraint stress (Ichijo et al. 2015, 2017). However, small volume differences have also been described in mammals, including small asymmetries in the LHb in mice (Zilles et al. 1976) and the MHb in rats (Wree et al. 1981). Interestingly, a unique clump of cells has also been described on the left habenula only in the macrosomatic mole (Kemali 1984).

In primates and humans, the study of subtle habenular volume asymmetry is more difficult due to the small relative size of the habenula and its internal position deep within the brain. However, left-right asymmetry appears to occur in the lateral habenula in humans (independent of age, brain weight and total habenular size) and is more prominent in women (Ahumada-Galleguillos et al. 2017). There also appears to be a functional asymmetry in the human habenula as evidenced by apparent differences in connectivity between left and right habenulae with the left habenula more coupled with the right parahippocampal regions and the right habenula more coupled with the substantia nigra/ventral tegmental regions (Hétu et al. 2016). Additionally, a high-resolution volumetric MR study found a trend (but not of significance) towards a larger left habenula volume in both healthy controls and patients with depression and bipolar affective disorder (Savitz et al. 2011b).

\section{Fasciculus retroflexus}

(Lt; backwards turning bunch/bundle) The fasciculus retroflexus, also known as the fasciculus retroflexus of Meynert, habenulointerpeduncular tract, habenulopeduncular tract or retroflex tract, is the final component of the DDCS and principal efferent of the habenula, running ventrally from the habenula to the ventral midbrain and hindbrain (Aizawa et al. 2011). Although originally described in 1872 as a tract originating from the habenula by Meynert (1872), Van Gehuchten was the first to define its distal end as joining the IPN (Van Gehuchten 1894). Similar to the SM, the FR is also bidirectional tract and contains fibers originating from both the lateral and medial habenula (Herkenham 1981).

\section{Anatomy}

Although described since 1892 by Meynert, specific anatomical information regarding the precise trajectory of this tract in humans is sparse. This is due to the bending nature of the tract as well as the fact that it traverses a particularly structurally dense white matter region of the midbrain. Overall, the FR appears to take a lyre shape as it descends from the habenula to the IPN (Naidich and Duvernoy 2009). In contrast to rats, where MHb fibers directly join the FR, human
$\mathrm{MHb}$ fibers initially travel along the ventral part of the $\mathrm{LHb}$ before descending to unite with the FR (Díaz et al. 2011). From the ventral aspect of the LHb, the FR travels down through the caudal thalamus, remaining medial to the centromedial nuclei (Naidich and Duvernoy 2009). It then curves medially, continuing ventrally in front of the pretectal area along the rostromedial border of the red nucleus, penetrating the nucleus near its rostral pole. At the level of the basal plate, it subsequently turns at $90^{\circ}$ caudally, to enter the IPN beneath the red nucleus. The abrupt change in direction is what gives this tract its name (retroflexus meaning recurve) Note that the FR enters the IPN from its rostral and dorsal borders (Naidich and Duvernoy 2009). The fibers here cross and recross the midline IPN several times forming a figure eight pattern (Morley 1986). Here they generate synapsis and appear to innervate both the ipsilatral and contralateral IPN (Contestabile and Flumerfelt 1981; Moreno-Bravo et al. 2016). An ill-defined nucleus of the interpeduncular tract has been documented in both animals (Rioch 1931) and humans (Marburg 1944). This nucleus consists of scattered neurons that lie between the medial and lateral parts of the tract and is of unknown function or significance.

Structurally, the FR consists of two concentric regions. A bundle of very thin unmyelinated axons originating exclusively from the $\mathrm{MHb}$ travel through its core, and terminate after criss-crossing in both the contra and ipsilateral interpeduncular nuclei (Benarroch 2015; Herkenham and Nauta 1979; Moreno-Bravo et al. 2016). Axons arising from the individual $\mathrm{MHb}$ subnuclei project down to specific regions of the IPN; dorsal $\mathrm{MHb}$ axons project to the lateral IPN, medial $\mathrm{MHb}$ axons to the ventral IPN, and lateral $\mathrm{MHb}$ axons to the dorsal IPN (Herkenham and Nauta 1979; Ichijo and Toyama 2015; Koppensteiner et al. 2016). Projections from MHb to IPN decrease caudally, with no afferents of the $\mathrm{MHb}$ reaching the caudal pole of the IPN (Contestabile and Flumerfelt 1981). The ventral MHb contains cholinergic neurons (Aizawa et al. 2012) and the dorsal MHb contain Substance P neurons of the dorsal MHb (Contestabile et al. 1987). The thicker myelinated fibers on the outer (mantle) FR emerge from the LHb (Benarroch 2015; Herkenham 1981), and to terminate directly in multiple monoaminergic nuclei including the ventral tegmental area, raphe nuclei, ventral periaqueductal gray and reticular formation. Note that the FR does not just consist of habenular efferents. Similar to other animals, the human FR also contains thalamic (pulvinar/midline nuclear group) fibers as well as ascending tectum fibers (Marburg 1944).

\section{Function}

Information relayed from the SM through the habenula is ultimately transmitted through the FR (Batalla et al. 2017) to the brainstem. Little specific information is available from 
human studies on the exact connectivity and function of the FR and as such most of its function is inferred from animal studies. Broadly speaking, the FR participates in inhibitory control of monoaminergic regions (Ellison 2002).

The core of the FR (i.e., originating from the $\mathrm{MHb}$ ) is the principal cholinergic input of the interpeduncular nucleus (Hattori et al. 1977). The IPN is well known for its widespread connections including ascending projections to the limbic system (hippocampus, entorhinal cortex and septal areas) and descending projections to the brainstem monoaminergic regions (VTA, raphe and periaqueductal gray) (Morley 1986). The IPN outputs that synapse with these modulatory regions are GABAergic (Lima et al. 2017). As such the MHb through the FR core exerts tonic inhibitory control on ascending monoaminergic neurons (Nishikawa et al. 1986). Blocking muscarinic cholinergic transmission in the IPN results in increased levels of dopamine metabolism in more frontal areas such as the medial prefrontal cortex and nucleus accumbens (Nishikawa et al. 1986). Bilateral lesioning of the FR in mice demonstrated a chronic increase in serotonin, noradrenaline and dopamine in the IPN (Takishita et al. 1990). Following lesioning, there was evidence of hyperinnervation of the IPN by the afferent fibers from the locus coeruleus (NA) (Battisti et al. 1987), raphe nucleus (serotonin) and other central areas (Takishita et al. 1990). This progressive alteration in monoamines within the IPN is suggested to be implicated in cognitive processes, specifically the deterioration of choice accuracy (Bianco and Wilson 2009).

The FR mediates most of the negative feedback between the dopamine-receiving forebrain and the dopamine-releasing brainstem through the lateral habenula (Ellison 2002). Continuous injections of dopaminergics, such as cocaine, MDMA, cathinone and amphetamine, in animals induced degeneration of the FR, particularly the outer sheath (Ellison 2002). The disintegration of the FR may also underlie the development of progressive neuropsychiatric effects associated with repeated binges in addiction disorders, including paranoia (Carlson et al. 2000; Ellison 1994).

Studies have demonstrated that the fasciculus retroflexus also has reciprocal ascending monoaminergic axons targeting the habenula (Smaha and Kaelber 1973; Skagerberg et al. 1984; $\mathrm{Li}$ et al. 1993). These axons are confined to the outer sheath of the FR and as such specifically connect with the lateral habenula (Skagerberg et al. 1984). The FR provides dense DA innervations to the $\mathrm{LHb}$, particularly its medial region, from the VTA and substantia nigra pars compacts (Skagerberg et al. 1984; Li et al. 1993; Shen et al. 2012). Previous literature suggest that DA has an inhibitory role in $\mathrm{LHb}$ and potentially is involved in the regulation of the habenular response to aversive and painful stimuli (Brown and Shepard 2013; Shen et al. 2012). Lesions of the FR weakened the density of dopaminergic nerve terminals in the LHb in rats (Shen et al. 2012; Skagerberg et al. 1984), indicating that the FR must be intact to transmit positive reward signals from the brainstem dopaminergic system to the LHb.

\section{Development}

As the name suggests, the DDCS is embryologically part of the diencephalon, a prosencephalic (forebrain) structure between the telencephalon and mesen- and rhombencephalon. Indeed, the main function of the DDCS components are as processing conduits to relay information between telencephalic and mesen/rhombencephalic structures. Similar to the development of other epithalamic gray matter structures, initially the habenular nuclei form early on, closely followed by their efferent and then followed by their afferent connections (Cho et al. 2014; Altman and Bayer 1979).

The diencephalon is formed of distinct segments, prosomeres (p1, p2 and p3) and neuromeres (D1, D2, D3, and D4), with circumferential axonal tracts forming around the neuromere boundaries (Funato et al. 2000). The habenula forms from the alar plate of $\mathrm{p} 2$ (Schmidt and Pasterkamp 2017), the SM is formed along D2 (Lim and Golden 2007) and the FR is formed along the p1/p2 boundary (Funato et al. 2000). Axon guidance molecules are expressed in adjacent neuromeres guiding the axonal growth (Funato et al. 2000). Among these molecules is the repulsive axon guidance molecule Sema3F. This is found in the diencephalon and is expressed in $\mathrm{p} 1$, leading to repulsion from habenular explants. Whereas Netrin-1, an attractant, is expressed from the caudal to the ventral regions of the diencephalon (Funato et al. 2000).

The larger neurons of the lateral nucleus develop before the smaller neurons of the medial nucleus in rodents (Angevine 1970), resulting in the establishment of a clear latero-medial or "outside-in" progression. This gradient appears to exist both across the whole habenula and within each lateral and medial habenular nuclei (Altman and Bayer 1979). In humans, habenular cytogenesis starts around the fifth week and is completed by approximately weeks 7-8 (Muller and O'Rahilly 1997) with the habenular commissure also present in most embryos by the start of the eighth week (Muller and O'Rahilly 1990).

The efferent white matter FR is characterized by immediate growth of axons from the developing habenula, with the FR extending towards the mesen/rhombencephalon and rapidly reaching the interpeduncular nucleus around the end of week 6 . The relationship of the FR and the parvocellular red nucleus is variable during development (Cho et al. 2014); however, the newly formed tract appears to migrate gradually towards the red nucleus to lodge into a deep groove on the medial aspect of the red nucleus sometime after week 
12 (Yamaguchi and Goto 2008). Embryologically, the FR appears to develop its complex trajectory along three decision points: (1) repulsive signals Sema $3 F$ and Sema5A complement the attractive signal Netrinl to funnel the developing FR along a corridor in front of the pretectum allowing dorsoventral extension from the habenula, (2) sudden retroflexion caudally due to Slit1 repulsion from the floor plate, and (3) finally criss-crossing across the IPN complexes (Moreno-Bravo et al. 2016). Myelination of the FR occurs much later in development, with completion sometime after 35 weeks (Yamaguchi and Goto 2008). Similar to other epithalamic structures, the afferent tract develops slightly later, with the SM forming from the telencephalic nuclei and eventually reaching the habenula around week 8 (Muller and O’Rahilly 1990).

\section{Conclusion}

This is the first review to describe in-depth all the components of the dorsal diencephalic conduction system: the stria medullaris, habenula and fasciculus retroflexus. The anatomy and connections of the DDCS reflect its function as an integrator of reward, motivational, cognitive and emotional information from diffuse basal forebrain regions within the habenular relay. From this hub, habenular outputs can modulate the regulatory brainstem regions. Despite the potential importance of this circuit in neuropsychiatric disorders, this review highlights the clear lack of human studies into the DDCS and its components in humans. What is known of the human DDCS appears inconsistent, particularly the specific networks of the habenular afferents and efferents. While there is an abundance of animal studies on the DDCS connections, there has been just one study that has physically traced the connections in humans (Marburg 1944), as such it is not clear whether many of these animal networks map accurately onto the larger human forebrain (Herculano-Houzel 2009). Furthermore, habenular function in humans has not been clearly defined, specifically with regards to the functional importance of known habenular laterality (Hétu et al. 2016), which appears to be of particular significance in other vertebrates (Ahumada-Galleguillos et al. 2017; Concha and Ahumada-Galleguillos 2016). The difficulty of studying such small anatomical structures in humans is without a doubt a contributor to the lack of replicable research of this system. This is particularly relevant for human in vivo studies, where imaging techniques struggle to capture the structures at current resolutions. New advances in neuroimaging such as increased scanner strengths, image acquisition improvements, and higher-order diffusion tractography (Tournier et al. 2011), functional imaging (Craddock et al. 2015) and magnetic resonance spectroscopy protocol refinements (Drago et al. 2018) may aid future investigations into the structure and function of the DDCS in humans in vivo. Additionally, more human post-mortem studies using established (e.g., DiI, horseradish peroxidase) (Von Bartheld et al. 1990; Schmued 1994; Tardif and Clarke 2001) and pioneering neurotracing methods (e.g., viral tracers) (Schmued 2016; Lai et al. 2018) to determine the diffuse basal forebrain connections of the DDCS neurocircuitry are needed to reveal the complicated habenular connectome. Further exploration of this pivotal system may progress our insight into the pathophysiology of many neuropsychiatric disorders, particularly major depressive disorders, anxiety disorders, addiction and pain disorders, and open novel therapeutics targets for investigation.

\section{References}

Ahumada-Galleguillos P, Lemus CG, Diaz E, Osorio-Reich M, Hartel S, Concha ML (2017) Directional asymmetry in the volume of the human habenula. Brain Struct Funct 222(2):1087-1092. https ://doi.org/10.1007/s00429-016-1231-z

Aizawa H, Amo R, Okamoto H (2011) Phylogeny and ontogeny of the habenular structure. Front Neurosci 5:138. https://doi. org/10.3389/fnins.2011.00138

Aizawa H, Kobayashi M, Tanaka S, Fukai T, Okamoto H (2012) Molecular characterization of the subnuclei in rat habenula. J Comp Neurol 520(18):4051-4066. https://doi.org/10.1002/ cne. 23167

Akagi K, Powell EW (1968) Differential projections of habenular nuclei. J Comp Neurol 132(2):263-274. https://doi.org/10.1002/ cne.901320204

Allen LS, Gorski RA (1991) Sexual dimorphism of the anterior commissure and massa intermedia of the human brain. J Comp Neurol 312(1):97-104. https://doi.org/10.1002/cne.903120108

Altman J, Bayer SA (1979) Development of the diencephalon in the rat. IV. Quantitative study of the time of origin of neurons and the internuclear chronological gradients in the thalamus. J Comp Neurol 188(3):455-471

Amat J, Sparks P, Matus-Amat P, Griggs J, Watkins L, Maier S (2001) The role of the habenular complex in the elevation of dorsal raphe nucleus serotonin and the changes in the behavioral responses produced by uncontrollable stress. Brain Res 917(1):118-126

Anderson CH, Shen CL (1980) Efferents of the medial preoptic area in the guinea pig: an autoradiographic study. Brain Res Bull 5(3):257-265

Angevine JB Jr (1970) Time of neuron origin in the diencephalon of the mouse. An autoradiographic study. J Comp Neurol 139(2):129-187

Araki M, McGeer PL, McGeer EG (1984) Retrograde HRP tracing combined with a pharmacohistochemical method for GABA transaminase for the identification of presumptive GABAergic projections to the habenula. Brain Res 304(2):271-277

Azmitia EC, Segal M (1978) An autoradiographic analysis of the differential ascending projections of the dorsal and median raphe nuclei in the rat. J Comp Neurol 179(3):641-667

Baker PM, Jhou T, Li B, Matsumoto M, Mizumori SJ, StephensonJones M, Vicentic A (2016) The lateral habenula circuitry: reward processing and cognitive control. J Neurosci 36(45):1148211488. https://doi.org/10.1523/JNEUROSCI.2350-16.2016

Ban T (1962) Experimental studies on the fiber connections of the rhinencephalon, 1. Med J Osaka Univ 12(3):385-424 
Batalla A, Homberg JR, Lipina TV, Sescousse G, Luijten M, Ivanova SA, Schellekens AFA, Loonen AJM (2017) The role of the habenula in the transition from reward to misery in substance use and mood disorders. Neurosci Biobehav Rev 80:276-285. https://doi.org/10.1016/j.neubiorev.2017.03.019

Battisti WP, Levin BE, Murray M (1987) Norepinephrine in the interpeduncular nucleus of the rat: normal distribution and the effects of deafferentation. Brain Res 418(2):287-300

Beckstead RM, Domesick VB, Nauta WJ (1979) Efferent connections of the substantia nigra and ventral tegmental area in the rat. Neuroanatomy. Springer, New York, pp 449-475

Benarroch EE (2015) Habenula: recently recognized functions and potential clinical relevance. Neurology 85(11):992-1000. https ://doi.org/10.1212/WNL.0000000000001937

Beretta CA, Dross N, Guiterrez-Triana JA, Ryu S, Carl M (2012) Habenula circuit development: past, present, and future. Front Neurosci 6:51. https://doi.org/10.3389/fnins.2012.00051

Berk ML, Finkelstein JA (1982) Efferent connections of the lateral hypothalamic area of the rat: an autoradiographic investigation. Brain Res Bull 8(5):511-526

Bianco IH, Wilson SW (2009) The habenular nuclei: a conserved asymmetric relay station in the vertebrate brain. Philos Trans R Soc Lond B Biol Sci 364(1519):1005-1020. https://doi. org/10.1098/rstb.2008.0213

Bischoff S, Leonhard S, Reymann N, Schuler V, Shigemoto R, Kaupmann K, Bettler B (1999) Spatial distribution of GABABR1 receptor mRNA and binding sites in the rat brain. J Comp Neurol 412(1):1-16

Björklund A, Owman C, West K (1972) Peripheral sympathetic innervation and serotonin cells in the habenular region of the rat brain. Zeitschrift für Zellforschung und mikroskopische Anatomie 127(4):570-579

Bobillier P, Pettijean F, Salvert D, Ligier M, Seguin S (1975) Differential projections of the nucleus raphe dorsalis and nucleus raphe centralis as revealed by autoradiography. Brain Res 85(2):205

Bobillier P, Seguin S, Degueurce A, Lewis B, Pujol J (1979) The efferent connections of the nucleus raphe centralis superior in the rat as revealed by radioautography. Brain Res 166(1):1-8

Bobillier P, Seguin S, Petitjean F, Salvert D, Touret M, Jouvet M (1976) The raphe nuclei of the cat brain stem: a topographical atlas of their efferent projections as revealed by autoradiography. Brain Res 113(3):449-486

Bocchetta M, Gordon E, Marshall CR, Slattery CF, Cardoso MJ, Cash DM, Espak M, Modat M, Ourselin S, Frisoni GB, Schott JM, Warren JD, Rohrer JD (2016) The habenula: an under-recognized area of importance in frontotemporal dementia? J Neurol Neurosurg Psychiatry 87(8):910-912. https://doi.org/10.1136/jnnp2015-312067

Boyd ES, Celso MB (1970) Effect of some brain lesions on septal intracranial self-stimulation in the rat. Am J Physiol 219(3):734741. https://doi.org/10.1152/ajplegacy.1970.219.3.734

Brinschwitz K, Dittgen A, Madai V, Lommel R, Geisler S, Veh R (2010) Glutamatergic axons from the lateral habenula mainly terminate on GABAergic neurons of the ventral midbrain. Neuroscience 168(2):463-476

Brown PL, Shepard PD (2013) Lesions of the fasciculus retroflexus alter footshock-induced cFos expression in the mesopontine rostromedial tegmental area of rats. PLoS ONE 8(4):e60678. https ://doi.org/10.1371/journal.pone.0060678

Buchanan, Frazer JE (1937) Buchanan's manual of anatomy including embryology. In: J. E. Frazer (ed), 6th edn. Bailliere, Tindall and Cox, London

Buchanan AR, Newton EB (1948) Functional neuroanatomy: including an atlas of the brain stem, 1st edn. Lea \& Febiger, Philadelphia

Buijs R (1978) Intra-and extrahypothalamic vasopressin and oxytocin pathways in the rat. Cell Tissue Res 192(3):423-435
Carceller-Sindreu M, de Diego-Adeliño J, Serra-Blasco M, VivesGilabert Y, Martín-Blanco A, Puigdemont D, Álvarez E, Pérez V, Portella MJ (2015) Volumetric MRI study of the habenula in first episode, recurrent and chronic major depression. Eur Neuropsychopharmacol 25(11):2015-2021. https://doi. org/10.1016/j.euroneuro.2015.08.009

Carl Huber G, Crosby EC (1929) The nuclei and fiber paths of the avian diencephalon, with consideration of telencephalic and certain mesencephalic centers and connections. J Comp Neurol 48(1):1-225

Carlson J, Armstrong B, Switzer Iii RC, Ellison G (2000) Selective neurotoxic effects of nicotine on axons in fasciculus retroflexus further support evidence that this a weak link in brain across multiple drugs of abuse. Neuropharmacology 39(13):2792-2798

Carpenter MB (1991) Core text of neuroanatomy. In: 4th ed. edn. Williams \& Wilkins, Baltimore

Carter D, Fibiger H (1978) The projections of the entopeduncular nucleus and globus pallidus in rat as demonstrated by autoradiography and horseradish peroxidase histochemistry. J Comp Neurol 177(1):113-123

Champney TH (2015) Essential clinical neuroanatomy. Wiley, Hoboken

Charles K, Evans M, Robbins M, Calver A, Leslie R, Pangalos M (2001) Comparative immunohistochemical localisation of GABAB1a, GABAB1b and GABAB2 subunits in rat brain, spinal cord and dorsal root ganglion. Neuroscience 106(3):447-467

Cho KH, Mori S, Jang HS, Kim JH, Abe H, Rodriguez-Vazquez JF, Murakami G (2014) The habenulo-interpeduncular and mammillothalamic tracts: early developed fiber tracts in the human fetal diencephalon. Childs Nerv Syst 30(9):1477-1484. https:// doi.org/10.1007/s00381-014-2432-5

Christoph GR, Leonzio RJ, Wilcox KS (1986) Stimulation of the lateral habenula inhibits dopamine-containing neurons in the substantia nigra and ventral tegmental area of the rat. J Neurosci 6(3):613-619

Coenen VA, Schumacher LV, Kaller C, Schlaepfer TE, Reinacher PC, Egger K, Urbach H, Reisert M (2018) The anatomy of the human medial forebrain bundle: ventral tegmental area connections to reward-associated subcortical and frontal lobe regions. NeuroImage Clinical 18:770-783

Concha ML, Ahumada-Galleguillos P (2016) An evolutionary perspective on habenular asymmetry in humans. J Neurol Neuromed $1: 44-50$

Concha ML, Wilson SW (2001) Asymmetry in the epithalamus of vertebrates. J Anat 199(Pt 1-2):63-84

Conrad LC, Leonard CM, Pfaff DW (1974) Connections of the median and dorsal raphe nuclei in the rat: an autoradiographic and degeneration study. J Comp Neurol 156(2):179-205

Conrad LC, Pfaff DW (1976a) Efferents from medial basal forebrain and hypothalamus in the rat. I. An autoradiographic study of the medial preoptic area. J Comp Neurol 169(2):185-219. https:// doi.org/10.1002/cne.901690205

Conrad LC, Pfaff DW (1976b) Efferents from medial basal forebrain and hypothalamus in the rat. II. An autoradiographic study of the anterior hypothalamus. J Comp Neurol 169(2):221-261. https:// doi.org/10.1002/cne.901690206

Contestabile A, Fonnum F (1983) Cholinergic and GABAergic forebrain projections to the habenula and nucleus interpeduncularis: surgical and kainic acid lesions. Brain Res 275(2):287-297

Contestabile A, Villani L, Fasolo A, Franzoni M, Gribaudo L, Øktedalen O, Fonnum F (1987) Topography of cholinergic and substance $P$ pathways in the habenulo-interpeduncular system of the rat. An immunocytochemical and microchemical approach. Neuroscience 21(1):253-270

Contestabile R, Flumerfelt B (1981) Afferent connections of the interpeduncular nucleus and the topographic organization of 
the habenulo-interpeduncular pathway: an HRP study in the rat. J Comp Neurol 196(2):253-270

Cornwall J, Cooper J, Phillipson O (1990) Afferent and efferent connections of the laterodorsal tegmental nucleus in the rat. Brain Res Bull 25(2):271-284

Cowan W, Raisman G, Powell T (1965) The connexions of the amygdala. J Neurol Neurosurg Psychiatry 28(2):137

Craddock RC, Tungaraza RL, Milham MP (2015) Connectomics and new approaches for analyzing human brain functional connectivity. Gigascience 4(1):13

Cragg B (1961) The connections of the habenula in the rabbit. Exp Neurol 3(4):388-409

Cruveilhier J (1836) Anatomie descriptive, vol 4. Béchet jeune, Paris

Curtis K, Viswanath H, Velasquez KM, Molfese DL, Harding MJ, Aramayo E, Baldwin PR, Ambrosi E, Madan A, Patriquin M, Frueh BC, Fowler JC, Kosten TR, Nielsen DA, Salas R (2017) Increased habenular connectivity in opioid users is associated with an $\alpha 5$ subunit nicotinic receptor genetic variant. Am J Addict 26(7):751-759. https://doi.org/10.1111/ajad.12607

Díaz C, Puelles L (1992) Afferent connections of the habenular complex in the lizard Gallotia galloti. Brain Behav Evol 39(5):312-324

Diaz E, Bravo D, Rojas X, Concha ML (2011) Morphologic and immunohistochemical organization of the human habenular complex. J Comp Neurol 519(18):3727-3747. https://doi. org/10.1002/cne.22687

Díaz E, Bravo D, Rojas X, Concha ML (2011) Morphologic and immunohistochemical organization of the human habenular complex. J Comp Neurol 519(18):3727-3747. https://doi. org/10.1002/cne.22687

Dong HW, Swanson LW (2006) Projections from bed nuclei of the stria terminalis, anteromedial area: cerebral hemisphere integration of neuroendocrine, autonomic, and behavioral aspects of energy balance. J Comp Neurol 494(1):142-178

Drago T, O'Regan PW, Welaratne I, Rooney S, O'Callaghan A, Malkit M, Roman E, Levins KJ, Alexander L, Barry D, O'Hanlon E, O'Keane V, Roddy D (2018) A comprehensive regional neurochemical theory in depression: a protocol for the systematic review and meta-analysis of 1H-MRS studies in major depressive disorder. Syst Rev 7(1):158

Dreosti E, Vendrell Llopis N, Carl M, Yaksi E, Wilson SW (2014) Left-right asymmetry is required for the habenulae to respond to both visual and olfactory stimuli. Curr Biol 24(4):440-445. https://doi.org/10.1016/j.cub.2014.01.016

Durkin MM, Gunwaldsen CA, Borowsky B, Jones KA, Branchek TA (1999) An in situ hybridization study of the distribution of the GABAB2 protein mRNA in the rat CNS. Mol Brain Res 71(2):185-200

Ellison G (1994) Stimulant-induced psychosis, the dopamine theory of schizophrenia, and the habenula. Brain Res Brain Res Rev 19(2):223-239

Ellison G (2002) Neural degeneration following chronic stimulant abuse reveals a weak link in brain, fasciculus retroflexus, implying the loss of forebrain control circuitry. Eur Neuropsychopharmacol 12(4):287-297

Ely BA, Xu J, Goodman WK, Lapidus KA, Gabbay V, Stern ER (2016) Resting-state functional connectivity of the human habenula in healthy individuals: associations with subclinical depression. Hum Brain Mapp 37(7):2369-2384. https://doi. org/10.1002/hbm.23179

Erpelding N, Sava S, Simons LE, Lebel A, Serrano P, Becerra L, Borsook D (2014) Habenula functional resting-state connectivity in pediatric CRPS. J Neurophysiol 111(2):239-247. https:// doi.org/10.1152/jn.00405.2013
Fakhoury M (2017) The habenula in psychiatric disorders: More than three decades of translational investigation. Neurosci Biobehav Rev. https://doi.org/10.1016/j.neubiorev.2017.02.010

Fakhoury M, Rompré PP, Boye SM (2016a) Role of the dorsal diencephalic conduction system in the brain reward circuitry. Behav Brain Res 296:431-441. https://doi.org/10.1016/j. bbr.2015.10.038

Fakhoury M, Voyer D, Lévesque D, Rompré PP (2016b) Effect of electrolytic lesions of the dorsal diencephalic conduction system on the distribution of Fos-like immunoreactivity induced by rewarding electrical stimulation. Neuroscience 334:214 225. https://doi.org/10.1016/j.neuroscience.2016.08.002

Faron-Górecka A, Kuśmider M, Kolasa M, Żurawek D, SzafranPilch K, Gruca P, Pabian P, Solich J, Papp M, DziedzickaWasylewska M (2016) Chronic mild stress alters the somatostatin receptors in the rat brain. Psychopharmacology 233(2):255-266

Faucette JR (1969) The olfactory bulb and medial hemisphere wall of the rat-fish. Chimaera J Comp Neurol 137(4):377-405

Felton TM, Linton L, Rosenblatt JS, Morell JI (1999) First and second order maternal behavior related afferents of the lateral habenula. NeuroReport 10(4):883-887

Ferrer NG (1969) Efferent projections of the anterior olfactory nucleus. J Comp Neurol 137(3):309-320. https://doi.org/10.1002/ cne. 901370305

Filion M, Harnois C (1978) A comparison of projections of entopeduncular neurons to the thalamus, the midbrain and the habenula in the cat. J Comp Neurol 181(4):763-780

Folgueira M, Anadón R, Yáñez J (2004) Experimental study of the connections of the telencephalon in the rainbow trout (Oncorhynchus mykiss). II: dorsal area and preoptic region. J Comp Neurol 480(2):204-233

Fore S, Palumbo F, Pelgrims R, Yaksi E (2017) Information processing in the vertebrate habenula. Semin Cell Dev Biol. https://doi. org/10.1016/j.semcdb.2017.08.019

Fore S, Yaksi E (2019) Habenula: a role in brain state transitions during coping behavior. Curr Biol 29(14):R692-R694. https://doi. org/10.1016/j.cub.2019.06.027

Funato H, Saito-Nakazato Y, Takahashi H (2000) Axonal growth from the habenular nucleus along the neuromere boundary region of the diencephalon is regulated by semaphorin $3 \mathrm{~F}$ and netrin- 1 . Mol Cell Neurosci 16(3):206-220

Furman DJ, Gotlib IH (2016) Habenula responses to potential and actual loss in major depression: preliminary evidence for lateralized dysfunction. Soc Cogn Affect Neurosci 11(5):843-851. https://doi.org/10.1093/scan/nsw019

Gamble H (1956) An experimental study of the secondary olfactory connexions in Testudo graeca. J Anat 90(Pt 1):15

Gamble HJ (1952) An experimental study of the secondary olfactory connexions in Lacerta viridis. J Anat 86(2):180-196

Gardon O, Faget L, Chu Sin Chung P, Matifas A, Massotte D, Kieffer BL (2014) Expression of mu opioid receptor in dorsal diencephalic conduction system: new insights for the medial habenula. Neuroscience 277:595-609. https://doi.org/10.1016/j.neuroscien ce.2014.07.053

Garland JC, Mogenson GJ (1983) An electrophysiological study of convergence of entopeduncular and lateral preoptic inputs on lateral habenular neurons projecting to the midbrain. Brain Res 263(1):33-41

Geisler S, Trimble M (2008) The lateral habenula: no longer neglected. CNS Spectr 13(6):484-489

Genton C (1969) Study, using the Nauta technique, of degeneration after electrolytic lesion of the septal region in the wood mouse (Apodemus sylvaticus). Brain Res 14(1):1-23

Goto M, Swanson LW, Canteras NS (2001) Connections of the nucleus incertus. J Comp Neurol 438(1):86-122 
Gottesfeld Z (1983) Origin and distribution of noradrenergic innervation in the habenula: a neurochemical study. Brain Res 275(2):299-304

Gottesfeld Z, Jacobowitz DM (1979) Cholinergic projections from the septal-diagonal band area to the habenular nuclei. Brain Res 176(2):391-394

Gottesfeld Z, Massari VJ, Muth EA, Jacobowitz DM (1977) Stria medullaris: a possible pathway containing GABAergic afferents to the lateral habenula. Brain Res 130(1):184-189

Greatrex RM, Phillipson OT (1982) Demonstration of synaptic input from prefrontal cortex to the habenula $i$ the rat. Brain Res 238(1):192-197

Groenewegen H, Berendse H, Haber S (1993) Organization of the output of the ventral striatopallidal system in the rat: ventral pallidal efferents. Neuroscience 57(1):113-142

Gruber C, Kahl A, Lebenheim L, Kowski A, Dittgen A, Veh RW (2007) Dopaminergic projections from the VTA substantially contribute to the mesohabenular pathway in the rat. Neurosci Lett 427(3):165-170. https://doi.org/10.1016/j.neulet.2007.09.016

Guillery RW (1959) Afferent fibres to the dorso-medial thalamic nucleus in the cat. J Anat 93:403-419

Gurdjian ES (1925) Olfactory connections in the albino rat, with special reference to the stria medullaris and the anterior commissure. JComp Neurol 38(2):127-163

Gurdjian ES (1927) The diencephalon of the albino rat. Studies on the brain of the rat No. 2. J Comp Neurol 43(1):1-114

Haber S, Lynd-Balta E, Mitchell S (1993) The organization of the descending ventral pallidal projections in the monkey. J Comp Neurol 329(1):111-128

Hahn JD, Swanson LW (2010) Distinct patterns of neuronal inputs and outputs of the juxtaparaventricular and suprafornical regions of the lateral hypothalamic area in the male rat. Brain Res Rev 64(1):14-103

Hahn JD, Swanson LW (2012) Connections of the lateral hypothalamic area juxtadorsomedial region in the male rat. J Comp Neurol 520(9):1831-1890

Hallanger AE, Levey AI, Lee HJ, Rye DB, Wainer BH (1987) The origins of cholinergic and other subcortical afferents to the thalamus in the rat. J Comp Neurol 262(1):105-124

Halpern ME, Liang JO, Gamse JT (2003) Leaning to the left: laterality in the zebrafish forebrain. Trends Neurosci 26(6):308-313

Hattori T, McGeer EG, Singh VK, McGeer PL (1977) Cholinergic synapse of the interpeduncular nucleus. Exp Neurol 55(3 PT 1):666-679

Hayakawa T, Seki M, Zyo K (1981) Studies on the efferent projections of the interpeduncular complex in cats. Okajimas Folia Anat Jpn 58(1):1-15

Hazrati L-N, Parent A (1991) Contralateral pallidothalamic and pallidotegmental projections in primates: an anterograde and retrograde labeling study. Brain Res 567(2):212-223

Heimer L (1972) The Olfactory Connections of the Diencephalon in the Rat; pp 504-523. Brain Behav Evol 6(1-6):504-523. https ://doi.org/10.1159/000123729

Hendricks M, Jesuthasan S (2007) Asymmetric innervation of the habenula in zebrafish. J Comp Neurol 502(4):611-619

Hennigan K, D'Ardenne K, McClure SM (2015) Distinct midbrain and habenula pathways are involved in processing aversive events in humans. J Neurosci 35(1):198-208. https://doi.org/10.1523/jneur osci.0927-14.2015

Herculano-Houzel S (2009) The human brain in numbers: a linearly scaled-up primate brain. Front Hum Neurosci 3:31

Herkenham M (1981) Anesthetics and the habenulo-interpeduncular system: selective sparing of metabolic activity. Brain Res 210(1-2):461-466

Herkenham M, Nauta WJ (1977) Afferent connections of the habenular nuclei in the rat. A horseradish peroxidase study, with a note on the fiber-of-passage problem. J Comp Neurol 173(1):123-146. https://doi.org/10.1002/cne.901730107

Herkenham M, Nauta WJ (1979) Efferent connections of the habenular nuclei in the rat. J Comp Neurol 187(1):19-47. https://doi. org/10.1002/cne.901870103

Herrick CJ (1948) The brain of the tiger salamander, Ambystoma tigrinum, vol VIII. University of Chicago Press, Chicago

Hétu S, Luo Y, Saez I, D’Ardenne K, Lohrenz T, Montague PR (2016) Asymmetry in functional connectivity of the human habenula revealed by high-resolution cardiac-gated resting state imaging. Hum Brain Mapp 37(7):2602-2615. https://doi. org/10.1002/hbm. 23194

Hikosaka O (2010) The habenula: from stress evasion to value-based decision-making. Nat Rev Neurosci 11(7):503-513. https://doi. org/10.1038/nrn2866

Hikosaka O, Sesack SR, Lecourtier L, Shepard PD (2008) Habenula: crossroad between the basal ganglia and the limbic system. J Neurosci 28(46):11825-11829. https://doi.org/10.1523/JNEUR OSCI.3463-08.2008

Hines M (1929) The brain of Ornithorhynchus anatinus. Philos Trans R Soc Lond Ser B Contain Pap Biol Character 217:155-287

Holstege G (2009) The mesopontine rostromedial tegmental nucleus and the emotional motor system: role in basic survival behavior. J Comp Neurol 513(6):559-565

Hoogland PV (1982) Brainstem afferents to the thalamus in a lizard, Varanus exanthematicus. J Comp Neurol 210(2):152-162

Hsu Y-WA, Wang SD, Wang S, Morton G, Zariwala HA, Horacio O, Turner EE (2014) Role of the dorsal medial habenula in the regulation of voluntary activity, motor function, hedonic state, and primary reinforcement. J Neurosci 34(34):11366-11384

Hsu Y-WA, Morton G, Guy EG, Wang SD, Turner EE (2016) Dorsal medial habenula regulation of mood-related behaviors and primary reinforcement by tachykinin-expressing habenula neurons. eNeuro. https://doi.org/10.1523/eneuro.0109-16.2016

Humphrey T (1936) The telencephalon of the bat. I. The non-cortical nuclear masses and certain pertinent fiber connections. J Comp Neurol 65(1):603-711

Ichijo H, Toyama T (2015) Axons from the medial habenular nucleus are topographically sorted in the fasciculus retroflexus. Anat Sci Int 90(4):229-234. https://doi.org/10.1007/ s12565-014-0252-z

Ichijo H, Hamada M, Takahashi S, Kobayashi M, Nagai T, Toyama T, Kawaguchi M (2015) Lateralization, maturation, and anteroposterior topography in the lateral habenula revealed by ZIF268/ EGR1 immunoreactivity and labeling history of neuronal activity. Neurosci Res 95:27-37. https://doi.org/10.1016/j.neure s.2015.01.005

Ichijo H, Nakamura T, Kawaguchi M, Takeuchi Y (2017) An Evolutionary hypothesis of binary opposition in functional incompatibility about habenular asymmetry in vertebrates. Front Neurosci. https://doi.org/10.3389/fnins.2016.00595

Ide JS, Li CS (2011) Error-related functional connectivity of the habenula in humans. Front Hum Neurosci 5:25. https://doi. org/10.3389/fnhum.2011.00025

Iwahori N (1977) A Golgi study on the habenular nucleus of the cat. J Comp Neurol 171(3):319-344

Jacobowitz DM, Palkovits M (1974) Topographic atlas of catecholamine and acetylcholinesterase-containing neurons in the rat brain. I. Forebrain (telencephalon, diencephalon). J Comp Neurol 157(1):13-28

Ji H, Shepard PD (2007) Lateral habenula stimulation inhibits rat midbrain dopamine neurons through a $\mathrm{GABA}(\mathrm{A})$ receptormediated mechanism. J Neurosci 27(26):6923-6930. https://doi. org/10.1523/JNEUROSCI.0958-07.2007

Johnson TN (1965) An experimental study of the fornix and hypothalamo-tegmental tracts in the cat. J Comp Neurol 125(1):29-39 
Kaufling J, Veinante P, Pawlowski SA, Freund-Mercier MJ, Barrot M (2009) Afferents to the GABAergic tail of the ventral tegmental area in the rat. J Comp Neurol 513(6):597-621

Kawaja MD, Flumerfelt BA, Hrycyshyn AW (1990) Synaptic organization of septal projections in the rat medial habenula: a wheat germ agglutinin-horseradish peroxidase and immunohistochemical study. Synapse 6(1):45-54

Kemali M (1984) Morphological asymmetry of the habenulae of a macrosmatic mammal, the mole. Jahrbuch für Morphologie und mikroskopische Anatomie 2 Abteilung, Zeitschrift für mikroskopisch-anatomische Forschung 98 (6):951-954

Kha HT, Finkelstein DI, Pow DV, Lawrence AJ, Horne MK (2000) Study of projections from the entopeduncular nucleus to the thalamus of the rat. J Comp Neurol 426(3):366-377

Kiening K, Sartorius A (2013) A new translational target for deep brain stimulation to treat depression. EMBO Mol Med 5(8):11511153. https://doi.org/10.1002/emmm.201302947

Kim JW, Naidich TP, Ely BA, Yacoub E, De Martino F, Fowkes ME, Goodman WK, Xu J (2016) Human habenula segmentation using myelin content. Neuroimage 130:145-156. https://doi. org/10.1016/j.neuroimage.2016.01.048

Kim R, Nakano K, Jayaraman A, Carpenter MB (1976) Projections of the globus pallidus and adjacent structures: an autoradiographic study in the monkey. J Comp Neurol 169(3):263-289

Kim U (2009) Topographic commissural and descending projections of the habenula in the rat. J Comp Neurol 513(2):173-187. https ://doi.org/10.1002/cne.21951

Kim U, Lee T (2012) Topography of descending projections from anterior insular and medial prefrontal regions to the lateral habenula of the epithalamus in the rat. Eur J Neurosci 35(8):1253-1269

Kizer J, Palkovits M, Brownstein M (1976) The projections of the A8, A9 and A10 dopaminergic cell bodies: evidence for a nigralhypothalamic-median eminence dopaminergic pathway. Brain Res 108(2):363-370

Klemm WR (2004) Habenular and interpeduncularis nuclei: shared components in multiple-function networks. Med Sci Monit 10(11):261-273

Kochanski RB, Dawe R, Eddelman DB, Kocak M, Sani S (2016) Identification of the stria medullaris thalami using diffusion tensor imaging. Neuroimage Clin 12:852-857. https://doi.org/10.1016/j. nicl.2016.10.018

Koppensteiner P, Galvin C, Ninan I (2016) Development-and experience-dependent plasticity in the dorsomedial habenula. Mol Cell Neurosci 77:105-112

Kowski AB, Geisler S, Krauss M, Veh RW (2008) Differential projections from subfields in the lateral preoptic area to the lateral habenular complex of the rat. J Comp Neurol 507(4):1465-1478. https://doi.org/10.1002/cne. 21610

Krishnan S, Mathuru AS, Kibat C, Rahman M, Lupton CE, Stewart J, Claridge-Chang A, Yen SC, Jesuthasan S (2014) The right dorsal habenula limits attraction to an odor in zebrafish. Curr Biol 24(11):1167-1175. https://doi.org/10.1016/j.cub.2014.03.073

Krug L, Wicht H, Northcutt RG (1993) Afferent and efferent connections of the thalamic eminence in the axolotl. Ambystoma Mex Neurosci Lett 149(2):145-148

Kusama T, Hagino N (1961) Medial forebrain bundle and stria medullaris thalami in rabbits. Psychiatry Clin Neurosci 15(3):229-245

Lai HM, Liu AKL, Ng HHM, Goldfinger MH, Chau TW, DeFelice J, Tilley BS, Wong WM, Wu W, Gentleman SM (2018) Next generation histology methods for three-dimensional imaging of fresh and archival human brain tissues. Nat Commun 9(1):1066

Larsen KD, McBride RL (1979) The organization of feline entopenduncular nucleus projections: anatomical studies. J Comp Neurol 184(2):293-308. https://doi.org/10.1002/cne.901840206

Larsen KD, Sutin J (1978) Output organization of the feline entopeduncular and subthalamic nuclei. Brain Res 157(1):21-31
Laursen AM (1955) An experimental study of pathways from the basal ganglia. J Comp Neurol 102(1):1-25

Lawson RP, Drevets WC, Roiser JP (2013) Defining the habenula in human neuroimaging studies. Neuroimage 64:722-727. https:// doi.org/10.1016/j.neuroimage.2012.08.076

Lawson RP, Nord CL, Seymour B, Thomas DL, Dayan P, Pilling S, Roiser JP (2017) Disrupted habenula function in major depression. Mol Psychiatry 22(2):202-208. https://doi.org/10.1038/ mp.2016.81

Lawson RP, Seymour B, Loh E, Lutti A, Dolan RJ, Dayan P, Weiskopf N, Roiser JP (2014) The habenula encodes negative motivational value associated with primary punishment in humans. Proc Natl Acad Sci USA 111(32):11858-11863. https://doi.org/10.1073/ pnas.1323586111

Lee HW, Kim SH, Kim JY, Kim H (2019) The role of the medial habenula cholinergic system in addiction and emotion-associated behaviors. Front Psychiatry 10:100

Leonard CM, Scott JW (1971) Origin and distribution of the amygdalofugal pathways in the rat: an experimental neuronatomical study. J Comp Neurol 141(3):313-329

Levins K, Roman E, Gallagher H, Murphy P, O'Regan P, Barry D, O'Keane V, O'Hanlon E, Roddy D (2019) AAPM 2019 annual meeting abstracts. Pain Med 20(3):583-660. https://doi. org/10.1093/pm/pny317

Li CS, Yan P, Chao HH, Sinha R, Paliwal P, Constable RT, Zhang S, Lee TW (2008) Error-specific medial cortical and subcortical activity during the stop signal task: a functional magnetic resonance imaging study. Neuroscience 155(4):1142-1151. https:// doi.org/10.1016/j.neuroscience.2008.06.062

Li K, Zhou T, Liao L, Yang Z, Wong C, Henn F, Malinow R, Yates JR, $\mathrm{Hu} \mathrm{H}$ (2013) $\beta \mathrm{CaMKII}$ in lateral habenula mediates core symptoms of depression. Science 341(6149):1016-1020. https ://doi.org/10.1126/science.1240729

Li YQ, Takada M, Shinonaga Y, Mizuno N (1993) The sites of origin of dopaminergic afferent fibers to the lateral habenular nucleus in the rat. J Comp Neurol 333(1):118-133

Lim Y, Golden JA (2007) Patterning the developing diencephalon. Brain Res Rev 53(1):17-26

Lima LB, Bueno D, Leite F, Souza S, Gonçalves L, Furigo IC, Donato J Jr, Metzger M (2017) Afferent and efferent connections of the interpeduncular nucleus with special reference to circuits involving the habenula and raphe nuclei. J Comp Neurol 525(10):2411-2442

Lindvall O, Björklund A (1974) The organization of the ascending catecholamine neuron systems in the rat brain as revealed by the glyoxylic acid fluorescence method. Acta Physiol Scand Suppl 412:1-48

Loo YT (1931) The forebrain of the opossum, Didelphis virginiana. Part II. Histology. J Comp Neurol 52(1):1-148

Loonen AJM, Kupka RW, Ivanova SA (2017) Circuits regulating pleasure and happiness in bipolar disorder. Front Neural Circuits 11:35. https://doi.org/10.3389/fncir.2017.00035

Maldonado M, Molfese DL, Viswanath H, Curtis K, Jones A, Hayes TG, Marcelli M, Mediwala S, Baldwin P, Garcia JM (2018) The habenula as a novel link between the homeostatic and hedonic pathways in cancer-associated weight loss: a pilot study. J Cachexia Sarcopenia Muscle 9(3):497-504

Marburg O (1944) The structure and fiber connections of the human habenula. J Comp Neurol 80(2):211-233

Markovic V, Agosta F, Canu E, Inuggi A, Petrovic I, Stankovic I, Imperiale F, Stojkovic T, Kostic VS, Filippi M (2017) Role of habenula and amygdala dysfunction in Parkinson disease patients with punding. Neurology 88(23):2207-2215. https:// doi.org/10.1212/WNL.0000000000004012

Massopust LC Jr, Thompson R (1962) A new interpedunculo-diencephalic pathway in rats and cats. J Comp Neurol 118(1):97-105 
McBride RL (1981) Organization of afferent connections of the feline lateral habenular nucleus. J Comp Neurol 198(1):89-99

Meibach RC, Siegel A (1977) Efferent connections of the septal area in the rat: an analysis utilizing retrograde and anterograde transport methods. Brain Res 119(1):1-20

Meye FJ, Lecca S, Valentinova K, Mameli M (2013) Synaptic and cellular profile of neurons in the lateral habenula. Front Hum Neurosci 7:860. https://doi.org/10.3389/fnhum.2013.00860

Meynert T (1872) Vom Gehirn der Säugetiere. In: Stricker S, Handbuch der Lehre von den Geweben der Menschen und Tiere, vol 2. Engelmann, Leipzig

Millhouse OE (1969) A Golgi study of the descending medial forebrain bundle. Brain Res 15(2):341-363

Mitchell R (1963) Connections of the habenula and of the interpeduncular nucleus in the cat. J Comp Neurol 121(3):441-457

Mizuno N, Clemente CD, Sauerland EK (1969) Fiber projections from rostral basal forebrain structures in the cat. Exp Neurol 25(2):220-237

Moore RY, Halaris AE, Jones BE (1978) Serotonin neurons of the midbrain raphe: ascending projections. J Comp Neurol 180(3):417-438

Moreno-Bravo JA, Martinez-Lopez JE, Madrigal MP, Kim M, Mastick GS, Lopez-Bendito G, Martinez S, Puelles E (2016) Developmental guidance of the retroflex tract at its bending point involves Robo1-Slit2-mediated floor plate repulsion. Brain Struct Funct 221(1):665-678

Moriizumi T, Hattori T (1992) Choline acetyltransferase-immunoreactive neurons in the rat entopeduncular nucleus. Neuroscience 46(3):721-728

Morin F (1950) An experimental study of hypothalamic connections in the guinea pig. J Comp Neurol 92(2):193-213

Morin L, Meyer-Bernstein E (1999) The ascending serotonergic system in the hamster: comparison with projections of the dorsal and median raphe nuclei. Neuroscience 91(1):81-105

Morley BJ (1986) The interpeduncular nucleus. Int Rev Neurobiol 28:157-182

Muller F, O'Rahilly R (1990) The human brain at stages 18-20, including the choroid plexuses and the amygdaloid and septal nuclei. Anat Embryol (Berl) 182(3):285-306

Muller F, O'Rahilly R (1997) The timing and sequence of appearance of neuromeres and their derivatives in staged human embryos. Acta Anat (Basel) 158(2):83-99

Muzerelle A, Scotto-Lomassese S, Bernard JF, Soiza-Reilly M, Gaspar $\mathrm{P}$ (2016) Conditional anterograde tracing reveals distinct targeting of individual serotonin cell groups (B5-B9) to the forebrain and brainstem. Brain Struct Funct 221(1):535-561

Nagy J, Carter D, Lehmann J, Fibiger H (1978) Evidence for a GABAcontaining projection from the entopeduncular nucleus to the lateral habenula in the rat. Brain Res 145(2):360-364

Naidich TP, Duvernoy HM (2009) Duvernoy's atlas of the human brain stem and cerebellum: high-field MRI : surface anatomy, internal structure, vascularization and 3D sectional anatomy. Springer, Wien

Najafi M, Kinnison J, Pessoa L (2017) Dynamics of intersubject brain networks during anxious anticipation. Front Hum Neurosci 11:552. https://doi.org/10.3389/fnhum.2017.00552

Nauta WJ (1956) An experimental study of the fornix system in the rat. J Comp Neurol 104(2):247-271

Nauta WJ, Mehler WR (1966) Projections of the lentiform nucleus in the monkey. Brain Res 1(1):3-42

Nauta WJH (1958) Hippocampal projections and related neural pathways to the mid-brain in the cat. Brain 81(3):319-340

Nishikawa T, Fage D, Scatton B (1986) Evidence for, and nature of, the tonic inhibitory influence of habenulointerpeduncular pathways upon cerebral dopaminergic transmission in the rat. Brain Res 373(1-2):324-336
Nolte J (2002) The human brain: an introduction to its functional anatomy. 5th ed. edn. Mosby, St. Louis, Mo.; London

Olucha-Bordonau FE, Teruel V, Barcia-González J, Ruiz-Torner A, Valverde-Navarro AA, Martínez-Soriano F (2003) Cytoarchitecture and efferent projections of the nucleus incertus of the rat. J Comp Neurol 464(1):62-97

Parent A (1979) Identification of the pallidal and peripallidal cells projecting to the habenula in monkey. Neurosci Lett 15(2-3):159-164

Parent A, Gravel S, Boucher R (1981) The origin of forebrain afferents to the habenula in rat, cat and monkey. Brain Res Bull 6(1):23-38

Parent M, Lévesque M, Parent A (2001) Two types of projection neurons in the internal pallidum of primates: single-axon tracing and three-dimensional reconstruction. J Comp Neurol 439(2):162-175

Parent MC (2013) Handling item-level missing data: simpler is just as good. Couns Psychol 41(4):568-600

Patestas MA, Gartner LP (2016) A textbook of neuroanatomy. Wiley, Hoboken

Phillipson O, Griffith A (1980) The neurones of origin for the mesohabenular dopamine pathway. Brain Res 197(1):213-218

Phillipson O, Pycock C (1982) Dopamine neurones of the ventral tegmentum project to both medial and lateral habenula. Exp Brain Res 45(1-2):89-94

Pierce ET, Foote WE, Hobson JA (1976) The efferent connection of the nucleus raphe dorsalis. Brain Res 107(1):137-144

Powell EW (1963) Septal efferents revealed by axonal degeneration in the rat. Exp Neurol 8(5):406-422

Powell EW (1966) Septal efferents in the cat. Exp Neurol 14(3):328-337

Powell EW (1968) Septohabenular connections in the rat, cat and monkey. J Comp Neurol 134(2):145-150

Powell EW, Leman RB (1976) Connections of the nucleus accumbens. Brain Res 105(3):389-403

Powell TP, Cowan WM, Raisman G (1965) The central olfactory connexions. J Anat 99(Pt 4):791-813

Price JL, Powell T (1970) The afferent connexions of the nucleus of the horizontal limb of the diagonal band. J Anat 107(Pt 2):239

Qin C, Luo M (2009) Neurochemical phenotypes of the afferent and efferent projections of the mouse medial habenula. Neuroscience 161(3):827-837

Quina LA, Tempest L, Ng L, Harris J, Ferguson S, Jhou T, Turner EE (2015) Efferent pathways of the mouse lateral habenula. J Comp Neurol 523(1):32-60. https://doi.org/10.1002/cne.23662

Raisman G (1966) The connexions of the septum. Brain 89(2):317-348

Ramon y Cajal S (1911) Histologie du syste me nerveux de I'Homme et des verte be s. Maloine (Paris) 2:891-942

Ranft K, Dobrowolny H, Krell D, Bielau H, Bogerts B, Bernstein HG (2010) Evidence for structural abnormalities of the human habenular complex in affective disorders but not in schizophrenia. Psychol Med 40(4):557-567. https://doi.org/10.1017/S0033 291709990821

Ranson S, Ranson M (1941) Fiber connections of corpus striatum as seen in Marchi preparations. Arch Neurol Psychiatry 46(2):230-249

Rausch LJ, Long CJ (1971) Habenular nuclei: a crucial link between the olfactory and motor systems. Brain Res 29(1):146-150

Rioch DM (1931) Studies on the diencephalon of Carnivora. Part III. Certain myelinated-fiber connections of the diencephalon of the $\operatorname{dog}$ (Canis familiaris), cat (Felis domestica), and aevisa (Crossarchus obscurus). J Comp Neurol 53(2):319-388

Risold P, Canteras N, Swanson L (1994) Organization of projections from the anterior hypothalamic nucleus: a Phaseolus vulgarisleucoagglutinin study in the rat. J Comp Neurol 348(1):1-40

Risold P, Swanson L (1995) Cajal's nucleus of the stria medullaris: characterization by in situ hybridization and 
immunohistochemistry for enkephalin. J Chem Neuroanat 9(4):235-240

Risold P, Swanson L (1997) Connections of the rat lateral septal complex. Brain Res Rev 24(2-3):115-195

Roddy DW, Roman E, Rooney S, Andrews S, Farrell C, Doolin K, Levins KJ, Tozzi L, Tierney P, Barry D, Frodl T, O'Keane V, O'Hanlon E (2018) Awakening neuropsychiatric research into the stria medullaris: development of a diffusion-weighted imaging tractography protocol of this key limbic structure. Front Neuroanat 12:39. https://doi.org/10.3389/fnana .2018 .00039

Rose EJ, Salmeron BJ, Ross TJ, Waltz J, Schweitzer JB, Stein EA (2017) Dissociable effects of cocaine dependence on reward processes: the role of acute cocaine and craving. Neuropsychopharmacology 42(3):736-747. https://doi.org/10.1038/npp.2016.161

Salas R, Baldwin P, de Biasi M, Montague PR (2010) BOLD responses to negative reward prediction errors in human habenula. Front Hum Neurosci 4:36. https://doi.org/10.3389/fnhum.2010.00036

Saper C, Swanson L, Cowan W (1979) An autoradiographic study of the efferent connections of the lateral hypothalamic area in the rat. J Comp Neurol 183(4):689-706

Sartorius A, Henn FA (2007) Deep brain stimulation of the lateral habenula in treatment resistant major depression. Med Hypotheses 69(6):1305-1308. https://doi.org/10.1016/j. mehy.2007.03.021

Sartorius A, Kiening KL, Kirsch P, von Gall CC, Haberkorn U, Unterberg AW, Henn FA, Meyer-Lindenberg A (2010) Remission of major depression under deep brain stimulation of the lateral habenula in a therapy-refractory patient. In: Biol Psychiatry, vol 67. vol 2. United States, pp e9-e11. 10.1016/j. biopsych.2009.08.027

Savitz JB, Bonne O, Nugent AC, Vythilingam M, Bogers W, Charney DS, Drevets WC (2011a) Habenula volume in post-traumatic stress disorder measured with high-resolution MRI. Biol Mood Anxiety Disord 1(1):7. https://doi.org/10.1186/2045-5380-1-7

Savitz JB, Nugent AC, Bogers W, Roiser JP, Bain EE, Neumeister A, Zarate CA Jr, Manji HK, Cannon DM, Marrett S, Henn F, Charney DS, Drevets WC (2011b) Habenula volume in bipolar disorder and major depressive disorder: a high-resolution magnetic resonance imaging study. Biol Psychiatry 69(4):336-343. https://doi.org/10.1016/j.biopsych.2010.09.027

Schmidt ER, Pasterkamp RJ (2017) The molecular mechanisms controlling morphogenesis and wiring of the habenula. Pharmacol Biochem Behav 162:29-37

Schmidt FM, Schindler S, Adamidis M, Strauss M, Trankner A, Trampel R, Walter M, Hegerl U, Turner R, Geyer S, Schonknecht $P$ (2017) Habenula volume increases with disease severity in unmedicated major depressive disorder as revealed by 7T MRI. Eur Arch Psychiatry Clin Neurosci 267(2):107-115. https://doi. org/10.1007/s00406-016-0675-8

Schmued LC (1994) Diagonal ventral forebrain continuum has overlapping telencephalic inputs and brainstem outputs which may represent loci for limbic/autonomic integration. Brain Res 667(2):175-191

Schmued LC (2016) Development and application of novel histochemical tracers for localizing brain connectivity and pathology. Brain Res 1645:31-35

Sheffield EB, Quick MW, Lester RA (2000) Nicotinic acetylcholine receptor subunit mRNA expression and channel function in medial habenula neurons. Neuropharmacology 39(13):2591-2603

Shelton L, Becerra L, Borsook D (2012a) Unmasking the mysteries of the habenula in pain and analgesia. Prog Neurobiol 96(2):208219. https://doi.org/10.1016/j.pneurobio.2012.01.004

Shelton L, Pendse G, Maleki N, Moulton EA, Lebel A, Becerra L, Borsook D (2012b) Mapping pain activation and connectivity of the human habenula. J Neurophysiol 107(10):2633-2648. https ://doi.org/10.1152/jn.00012.2012

Shen X, Ruan X, Zhao H (2012) Stimulation of midbrain dopaminergic structures modifies firing rates of rat lateral habenula neurons. PLoS ONE 7(4):e34323. https://doi.org/10.1371/journ al.pone. 0034323

Shepard PD, Holcomb HH, Gold JM (2006) Schizophrenia in translation: the presence of absence: habenular regulation of dopamine neurons and the encoding of negative outcomes. Schizophr Bull 32(3):417-421

Shinoda K, Tohyama M (1987) Analysis of the habenulopetal enkephalinergic system in the rat brain: an immunohistochemical study. J Comp Neurol 255(4):483-496

Sim LJ, Joseph SA (1991) Arcuate nucleus projections to brainstem regions which modulate nociception. J Chem Neuroanat 4(2):97-109

Simon H, Le Moal M, Calas A (1979) Efferents and afferents of the ventral tegmental-A10 region studied after local injection of [3H] leucine and horseradish peroxidase. Brain Res 178(1):17-40

Skagerberg G, Lindvall O, Bjo A (1984) Origin, course and termination of the mesohabenular dopamine pathway in the rat. Brain Res 307(1-2):99-108

Smaha LA, Kaelber WW (1973) Efferent fiber projections of the habenula and the interpeduncular nucleus. An experimental study in the opossum and cat. Exp Brain Res 16(3):291-308

Sofroniew M, Weindl A, Schrell U, Wetzstein R (1981) Immunohistochemistry of vasopressin, oxytocin and neurophysin in the hypothalamus and extrahypothalamic regions of the human and primate brain. Acta Histochemica Supplementband 24:79-95

Staines W, Yamamoto T, Dewar K, Daddona P, Geiger J, Nagy J (1988) Distribution, morphology and habenular projections of adenosine deaminase-containing neurons in the septal area of rat. Brain Res 455(1):72-87

Strotmann B, Heidemann RM, Anwander A, Weiss M, Trampel R, Villringer A, Turner R (2014) High-resolution MRI and diffusion-weighted imaging of the human habenula at 7 tesla. $\mathbf{J}$ Magn Reson Imaging 39(4):1018-1026. https://doi.org/10.1002/ jmri.24252

Sutherland RJ (1982) The dorsal diencephalic conduction system: a review of the anatomy and functions of the habenular complex. Neurosci Biobehav Rev 6(1):1-13

Swanson L (1982) The projections of the ventral tegmental area and adjacent regions: a combined fluorescent retrograde tracer and immunofluorescence study in the rat. Brain Res Bull 9(1-6):321-353

Swanson LW (1976) An autoradiographic study of the efferent connections of the preoptic region in the rat. J Comp Neurol 167(2):227-256. https://doi.org/10.1002/cne.901670207

Swanson LW, Cowan WM (1979) The connections of the septal region in the rat. J Comp Neurol 186(4):621-655. https://doi. org/10.1002/cne. 901860408

Takishita N, Kubo H, Mitani A, Nakamura Y, Masuda S, Iwahashi K, Kataoka K (1990) Differential effects of fasciculus retroflexus lesions on serotonin, glutamate and gamma-aminobutyrate content and choline acetyltransferase activity in the interpeduncular nucleus. Brain Res Bull 25(4):569-574

Tardif E, Clarke S (2001) Intrinsic connectivity of human auditory areas: a tracing study with DiI. Eur J Neurosci 13(5):1045-1050

Tarin P (1750)Adversaria Anatomica. De omnibus corporis humani partium, tum descriptionibus, cum picturis. Adversaria anatomica prima, nervorum et organorum functionibus animalibus inserventium, descriptionibus et iconismis. Parisiis, Paris

Torrisi S, Nord CL, Balderston NL, Roiser JP, Grillon C, Ernst M (2017) Resting state connectivity of the human habenula at ultrahigh field. Neuroimage 147:872-879. https://doi.org/10.1016/j. neuroimage.2016.10.034 
Tournier JD, Mori S, Leemans A (2011) Diffusion tensor imaging and beyond. Magn Reson Med 65(6):1532-1556. https://doi. org/10.1002/mrm.22924

Tripathi A, Prensa L, Mengual E (2013) Axonal branching patterns of ventral pallidal neurons in the rat. Brain Struct Funct 218(5):1133-1157

Troiano R, Siegel A (1975) The ascending and descending connections of the hypothalamus in the cat. Exp Neurol 49(1):161-173

Troiano R, Siegel A (1978a) Efferent connections of the basal forebrain in the cat: the nucleus accumbens. Exp Neurol 61(1):185-197

Troiano R, Siegel A (1978b) Efferent connections of the basal forebrain in the cat: the substantia innominata. Exp Neurol 61(1):198-213

Ullsperger M, von Cramon DY (2003) Error monitoring using external feedback: specific roles of the habenular complex, the reward system, and the cingulate motor area revealed by functional magnetic resonance imaging. J Neurosci 23(10):4308-4314

Valenstein ES, Nauta WJ (1959) A comparison of the distribution of the fornix system in the rat, guinea pig, cat, and monkey. J Comp Neurol 113(3):337-363

Van Der Kooy D, Carter DA (1981) The organization of the efferent projections and striatal afferents of the entopeduncular nucleus and adjacent areas in the rat. Brain Res 211(1):15-36

Van Gehuchten AJLC (1894) Contribution à l'étude du Système nerveux des téléostéens 10:255-295

Varga V, Kocsis B, Sharp T (2003) Electrophysiological evidence for convergence of inputs from the medial prefrontal cortex and lateral habenula on single neurons in the dorsal raphe nucleus. Eur J Neurosci 17(2):280-286

Vertes RP (2002) Analysis of projections from the medial prefrontal cortex to the thalamus in the rat, with emphasis on nucleus reuniens. J Comp Neurol 442(2):163-187

Vertes RP (2004) Differential projections of the infralimbic and prelimbic cortex in the rat. Synapse 51(1):32-58

Vertes RP, Fortin WJ, Crane AM (1999) Projections of the median raphe nucleus in the rat. Journal of Comparative Neurology 407(4):555-582

Vertes RP, Martin GF (1988) Autoradiographic analysis of ascending projections from the pontine and mesencephalic reticular formation and the median raphe nucleus in the rat. J Comp Neurol 275(4):511-541

Vesalius A (1543) Andreae Vesalii de humani corporis fabrica libri septem. ex officina Joannis Oporini, Basileæ

Vincent S, Kimura H, McGeer E (1982) A histochemical study of GABA-transaminase in the efferents of the pallidum. Brain Res 241(1):162-165

Vincent SR, Brown JC (1986) Somatostatin immunoreactivity in the entopeduncular projection to the lateral habenula in the rat. Neurosci Lett 68(2):160-164

Viswanath H, Carter AQ, Baldwin PR, Molfese DL, Salas R (2013) The medial habenula: still neglected. Front Hum Neurosci 7:931. https://doi.org/10.3389/fnhum.2013.00931

Von Bartheld C, Cunningham D, Rubel E (1990) Neuronal tracing with DiI: decalcification, cryosectioning, and photoconversion for light and electron microscopic analysis. J Histochem Cytochem 38(5):725-733

von Bartheld CS, Meyer DL (1990) Paraventricular organ of the lungfish Protopterus dolloi: morphology and projections of CSFcontacting neurons. J Comp Neurol 297(3):410-434

von Soemmerring ST (1791) Abbildungen und Beschreibungen einiger Missgeburten die sich ehemals auf dem anatomischen Theater zu Cassel befanden. Universitätsbuchhandlung, Mainz

Wallace ML, Saunders A, Huang KW, Philson AC, Goldman M, Macosko EZ, McCarroll SA, Sabatini BL (2017) Genetically distinct parallel pathways in the entopeduncular nucleus for limbic and sensorimotor output of the basal ganglia. Neuron 94(1):138-152. e135
Wang D-G, Gong N, Luo B, Xu T-L (2006) Absence of GABA type A signaling in adult medial habenular neurons. Neuroscience 141(1):133-141

Watson C, Paxinos G (1986) The rat brain in stereotaxic coordinates. Academic press, San Diego

Weller KL, Smith DA (1982) Afferent connections to the bed nucleus of the stria terminalis. Brain Res 232(2):255-270

Wenzel JaW, Wenzel C (1812) penitiori structura cerebri hominis et brutorum. Tubingae

Wolf G, Sutin J (1966) Fiber degeneration after lateral hypothalamic lesions in the rat. J Comp Neurol 127(2):137-156. https://doi. org/10.1002/cne. 901270202

Wree A, Zilles K, Schleicher A (1981) Growth of fresh volumes and spontaneous cell death in the nuclei habenulae of albino rats during ontogenesis. Anat Embryol 161(4):419-431

Yamadori T (1969) Efferent fibers of the habenula and stria medullaris thalami in rats. Exp Neurol 25(4):541-558

Yamaguchi K, Goto N (2008) Development of the human parvocellular red nucleus. Dev Neurosci 30(5):325-330

Yañez J, Anadon R (1994) Afferent and efferent connections of the habenula in the larval sea lamprey (Petromyzon marinus $\mathrm{L}$ ): an experimental study. J Comp Neurol 345(1):148-160

Yañez J, Anadón R (1996) Afferent and efferent connections of the habenula in the rainbow trout (Oncorhynchus mykiss): an indocarbocyanine dye (DiI) study. J Comp Neurol 372(4):529-543

Yang N, Anapindi KD, Rubakhin SS, Wei P, Yu Q, Li L, Kenny PJ, Sweedler JV (2018) Neuropeptidomics of the rat habenular nuclei. J Proteome Res 17(4):1463-1473

Yetnikoff L, Cheng AY, Lavezzi HN, Parsley KP, Zahm DS (2015) Sources of input to the rostromedial tegmental nucleus, ventral tegmental area, and lateral habenula compared: a study in rat. J Comp Neurol 523(16):2426-2456

Young MW (1936) The nuclear pattern and fiber connections of the non-cortical centers of the telencephalon of the rabbit (Lepus cuniculus). J Comp Neurol 65(1):295-401

Zahm DS, Williams E, Wohltmann C (1996) Ventral striatopallidothalamic projection: IV. Relative involvements of neurochemically distinct subterritories in the ventral pallidum and adjacent parts of the rostroventral forebrain. J Comp Neurol 364(2):340-362

Zhang L, Wang H, Luan S, Yang S, Wang Z, Wang J, Zhao H (2017) Altered volume and functional connectivity of the habenula in schizophrenia. Front Hum Neurosci 11:636. https://doi. org/10.3389/fnhum.2017.00636

Zhao H, Rusak B (2005) Circadian firing-rate rhythms and light responses of rat habenular nucleus neurons in vivo and in vitro. Neuroscience 132(2):519-528. https://doi.org/10.1016/j.neuro science.2005.01.012

Zhao-Shea R, Liu L, Pang X, Gardner PD, Tapper AR (2013) Activation of GABAergic neurons in the interpeduncular nucleus triggers physical nicotine withdrawal symptoms. Curr Biol 23(23):2327-2335

Zilles K, Schleicher A, Wingert F (1976) Quantitative growth analysis of limbic nuclei areas fresh volume in diencephalon and mesencephalon of an albino mouse ontogenic series III Nucleus interpe-uncularis. J fur Hirnforschung 17(1):21-29

Zyo K (1963) Experimental studies on the medial forebrain bundle, medial longitudinal fasciculus and supraoptic decussations in the rabbit. Med J Osaka Univ 13(2):193-239

Publisher's Note Springer Nature remains neutral with regard to jurisdictional claims in published maps and institutional affiliations. 